\title{
A People's History of Collective Action Clauses
}

\author{
W. MARK C. WEIDEMAIER \& MitU GULATI ${ }^{*}$
}

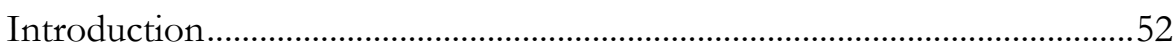

I. The Modern CAC Legend ....................................................................55

A. The Ascendance of CACs - Mexico, 2003 ............................57

1. New Problems Require New Solutions ...........................58

2. The Public Sector as a Driver of Innovation.................60

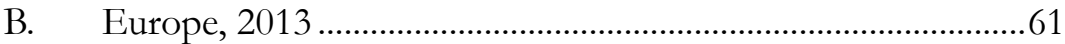

II. Nothing New Under the Sun ...............................................................62

A. Description of the Data ...............................................................63

B. A Contracts History of the Bond Markets................................64

1. Collective Acceleration Clauses in Earlier Eras of Bond Lending ...................................................................65

2. Modification Clauses and Their Substitutes...................70

a. The (Marginal) History of Modification Clauses .................................................................... 70

b. The Case of the (Not-so) Mistaken CACs in New York ..........................................................74

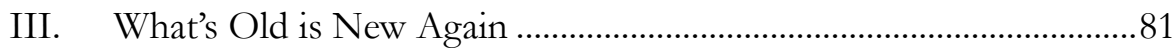

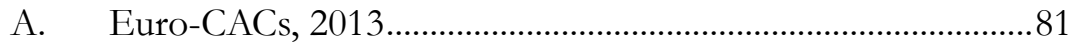

B. CACs as the Latest Fashion in Contract Reform ......................82

Appendix 1: 1923 Czech Bond ..........................................................................85

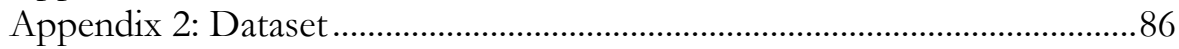

* Faculty at the University of North Carolina School of Law and Duke University School of Law, respectively. For comments and suggestions, thanks to Anna Gelpern, Marc Flandreau, Ugo Panizza, Christoph Trebesch, and the participants in a December 2012 conference on the history of sovereign debt at the Graduate Institute in Geneva. 
"In order to... [prevent future crises], standardized and identical collective action clauses (CACs) will be included... in the terms and conditions of all new euro area government bonds ...."

- Statement by the Eurogroup, November 28, 20101

"CACs. Why'd it have to be CACs?"

- Dr. Henry Walton "Indiana” Jones, $\mathrm{Jr}^{2}$

\section{INTRODUCTION}

After a half-century, Depression-induced slumber, the market for sovereign bonds awakened in the early 1990s. It did so on the heels of a financial crisis triggered by widespread sovereign defaults on commercial bank loans. Under a plan developed by U.S. Secretary of the Treasury Nicholas Brady, these illiquid commercial loans were restructured and replaced by tradable bonds - a process that reinvigorated the bond markets but did not herald a new era of economic security. ${ }^{3}$ Between 1995 and 2002, three new crises erupted, and the official sector repeatedly extended unpopular bailouts to debtor nations. ${ }^{4}$ A consensus emerged that the international financial architecture was broken. The system required a mechanism to ensure that private lenders bore the cost of their improvident loans, thus discouraging them from making such loans in the first place. ${ }^{5}$ Otherwise, the cycle of over-borrowing, default, and bailouts would continue.

For nearly a decade, policymakers and market actors debated solutions. A multilateral treaty establishing a bankruptcy court for sovereigns? A fine idea, some thought, but it was politically infeasible. ${ }^{6}$ And anyway, what if the problem could be addressed without such a drastic intervention? Some - in particular, officials at the U.S. Department of the Treasury thought that the problem could be fixed by changing the terms of bond

\footnotetext{
1. Press Release, Council of the European Union, Statement by the Eurogroup 1-2 (Nov. 28, 2010) [hereinafter Eurogroup Press Release], available at http://www.consilium.europa.eu/uedocs/cms_Data/docs/pressdata/en/ecofin/118050.pdf.

2. Our apologies to Harrison Ford. The actual quote ("Snakes. Why'd it have to be snakes?") appears in the movie Raiders of the Lost Ark. See RAIDERS OF THE LOST ARK (Paramount Pictures 1981).

3. For a discussion of the development of this market in the early 1990s, see Ross P. Buckley, The Facilitation of the Brady Plan: Emerging Markets Trading from 1989 to 1993, 21 FORDHAM INT’L L.J. 1802 (1997).

4. See, e.g., John B. TAYlor, Global FinAnCial Warriors 100 (2007); Stephen J. Choi et al., The Dynamics of Contract Evolution, 88 N.Y.U. L. REv. 1, 17 (2013).

5. See, e.g., Ross P. Buckley, Sovereign Bankruptcy, 15 BOND L. REV. 95 (2003) (advocating bankruptcy regime as mechanism for dealing with sovereign default).

6. For a general discussion of the events leading up to the adoption of CACs in the New York law market, see Anna Gelpern \& Mitu Gulati, Public Symbol in Private Contract: A Case Study, 84 WASH. U. L. REV. 1627, 1649-60 (2006).
} 
contracts. ${ }^{7}$ These advocates recognized that the crises of the late $1990 \mathrm{~s}$ and early 2000s involved countries that often issued bonds governed by New York law. ${ }^{8}$ These bonds were the poster children for contract reform. Unlike the orderly, collective workout envisioned by bankruptcy laws, New York-law sovereign bonds gave each holder the contractual right to opt out of a restructuring. ${ }^{\text {A }}$ bondholder might exploit this right, delaying a restructuring that would benefit the group as a whole by demanding a better deal for itself. ${ }^{10}$ To fix the problem, some observers claimed, ${ }^{11}$ bonds should adopt new terms, called Collective Action Clauses (CACs), that allowed for collectively binding restructuring decisions.

Reformers promoted two types of CACs in particular. ${ }^{12}$ The first was a collective modification clause, which allows a defined percentage of bondholders to accept a restructuring proposal in a way that will bind the entire group. ${ }^{13}$ The second was a collective acceleration clause, which prevents individual bondholders from demanding full payment after a default and instead requires a minimum bondholder vote to approve such a demand. ${ }^{14}$ Both clauses limit the ability of dissenting bondholders to threaten litigation or otherwise hold up a restructuring. ${ }^{15}$ To their proponents in the official sector, these features meant that CACs might

\footnotetext{
7. See id.

8. See W. Mark C. Weidemaier \& Mitu Gulati, How Markets Work: The Lanyer's Version, STUD. L., POL., \& SOC’Y (forthcoming 2013) (manuscript at 9), available at http://papers.ssrn.com/sol3/papers.cfm?abstract_id=1886435.

9. See id. (manuscript at 22-23).

10. See Barry Eichengreen, Restructuring Sovereign Debt, 17 J. ECON. PERSP. 75, 77 (2003); Kenneth M. Kletzer, Sovereign Bond Restructuring: Collective Action Clauses and Official Crisis Intervention 17-18 (Int'l Monetary Fund, Working Paper No. 03/134, 2003), available at http://www.imf.org/external/pubs/ft/wp/2003/wp03134.pdf.

11. See Gelpern \& Gulati, supra note 6, at 1629-30, 1640.

12. As a theoretical matter, one might use the term CAC to encompass a variety of contract terms designed to ease bondholder coordination problems. For example, (1) trustee clauses empower a trustee to act on behalf of bondholders collectively; (2) bondholder committee or representative clauses allow for the creation of a committee or the appointment of a representative to negotiate on behalf of bondholders after a default, but not to make binding decisions; (3) acceleration clauses prevent bondholders from demanding full payment of their principal after a default, unless a defined percentage of the group approves the demand; (4) modification clauses allow a defined percentage of bondholders to approve a restructuring proposal in a vote that will bind all holders of that bond; and (5) aggregation clauses allow for a similar vote to occur across different bond issues. For descriptions of these variations, see Michael Bradley \& G. Mitu Gulati, Collective Action Clauses for the Eurozone: An Empirical Analysis (Mar. 28, 2013) (unpublished manuscript) (manuscript at 17 25), available at http://ssrn.com/abstract $=1948534$; Weidemaier \& Gulati, supra note 8, (manuscript at
} $5-7)$.

13. See Weidemaier \& Gulati, supra note 8, (manuscript at 5-6).

14. See, e.g., SusAn SCHADler, CTR. FOR INT’L GOVERNANCE INNOVATION \& INST. FOR NeW Econ. Thinking, Cigi Paper No. 6, SOVereign Debtors in Distress: Are Our INSTITUTIONS UP TO THE CRISIS? 15 (2012), available at http://www.cigionline.org/publications/2012/8/sovereign-debtors-distress-are-our-institutions-upchallenge (referring to such clauses as majority enforcement clauses).

15. Id. 
also reduce the need for bailouts. Proponents believed that private investors would be more willing to accept a restructuring if they were not worried that holdouts would later extract a better deal.

In February 2003, this policy idea became reality. After a long Treasuryled campaign, a major sovereign issuer, Mexico, issued New York-law bonds with both types of CACs: collective modification and collective acceleration provisions. ${ }^{16}$ In the wake of Mexico's issuance, many other countries also adopted these terms in New York-law bonds. ${ }^{17}$ More significantly, CACs have assumed pride of place as a key component of the official sector's response to sovereign debt crises. ${ }^{18}$ So entrenched are CACs in this role that today - nearly a decade later - they have swiftly emerged as a key piece of the Eurozone's response to its crisis. ${ }^{19}$ As we write, some reformers even propose CACs as a solution to the woes of the U.S. municipal bond market. ${ }^{20}$

Proposals to reform sovereign bond contracts, however, encounter an objection. The bonds are drafted and traded by sophisticated actors in thick markets. If market actors have not already chosen to use CACs, perhaps these terms are not such a good idea after all. Over time, a market-failure story emerged to counter this objection. The story emphasized history and, in its simplest form, posited that CACs were a novel innovation necessary to address modern problems that market participants did not yet fully understand. ${ }^{21}$ In the jargon of our economist colleagues, market actors had been operating with incomplete information.

In this paper, we will examine this narrative against the historical record. In doing so, we hope to advance the literature in two respects. First, most of the attention in reform debates has focused on modification clauses, which, as a reminder, allow for a collectively binding restructuring vote. But collective acceleration clauses were also a key part of reform proposals in the 1990s and early 2000s. We will present evidence that collective acceleration clauses have been used in sovereign bonds for nearly a century. Second, we have found that collective modification clauses have also been in use for much longer than is commonly believed but that market

\footnotetext{
16. John Drage \& Catherine Hovaguimian, Collective action Clauses (CACs): An ANAlysis of Provisions InCluded in RECENT SOVEREIGN BOND IsSues 2 (2004), available at http://www.bankofengland.co.uk/publications/Documents/fsr/2004/fsr17art9.pdf.

17. See infra Figure 1 and Table 1.

18. See infra Part I.

19. See infra Part I.B.

20. See, e.g., Field Hearing on the State of the Municipal Securities Market Before the Sec. \& Exch. Comm'n 5-6 (July 29, 2011) (statement of James E. Spiotto, Chapman \& Cutler LLP) [hereinafter Remarks of James E. Spiotto], available at http://www.sec.gov/spotlight/municipalsecurities/statements072911/spiotto.pdf. Thanks to Anna Gelpern for pointing us to this material.

21. See infra Part I.
} 
participants did not (at least until recently) seem to assign these clauses much value. Indeed, we will recount episodes in which protracted debtrestructuring negotiations took place without any of the involved parties seeming to notice that the relevant debt already included modification clauses. These findings undercut the historical narrative supporting pro-CAC initiatives, which posits that CACs are novel clauses that were unfamiliar to market participants. To the contrary, the evidence suggests that market participants were well-aware of CACs but did not believe them to be a necessary feature of sovereign bond documentation.

We have no quarrel with the current CAC initiative in the Eurozone. And we accept that CACs can reduce the barriers to restructuring in at least some cases. Rather, we contend that the pro-CAC historical narrative rests on flawed premises. CACs have been in use for nearly a century, including in some Eurozone local-law bonds, which are the focus of the current Eurozone reform efforts. For most of that century, however, drafters used other clauses, such as trustee clauses, to facilitate bondholder coordination and to limit the power of holdout creditors to disrupt a restructuring. What the pro-CAC narrative fails to explain is why CACs, so long a marginal part of sovereign bond documentation, have now become integral to the proper management of public debt crises. Without such an explanation, CACs look less like a promising policy innovation and more like the latest fashion in financial-market reform.

\section{THE MODERN CAC LEGEND}

The crises of the 1990s and 2000s prompted much reflection on the sovereign debt markets and the lack of a bankruptcy-type mechanism to deal with insolvent sovereigns. Such reflection was not new; academics, lawyers, and policymakers have long engaged these questions, although they have not always agreed on the problems or their solutions. ${ }^{22} \mathrm{By}$ the mid-1990s, however, problems of collective action and moral hazard were the primary topics of discussion. The bond markets had sprung back to life after the Latin American debt crisis of the 1980s, and some feared that this development, along with the interconnected nature of global markets, might exacerbate these problems. ${ }^{23}$ By the early 2000s, the debate had focused on two competing approaches. ${ }^{24}$ One proposal, introduced by

22. See, e.g., Kenneth Rogoff \& Jeromin Zettelmeyer, Bankruptcy Procedures for Sovereigns: A History of Ideas, 1976-2001, 49 IMF STAFF PAPERS 470 (2002), available at http://www.imf.org/External/Pubs/FT/staffp/2002/03/pdf/rogoff.pdf.

23. See Barry Eichengreen \& Richard Portes, Ctr. for Econ. Policy Research, CRISIS? WHAT CRISIS? ORDERLY WORKOUTS FOR SOVEREIGN DEBTORS (1995); Richard Portes, Resolution of Sovereign Debt Crises: The New Old Framework (Ctr. for Econ. Policy Research, Discussion Paper No. 4714, 2004), available at http:/ / faculty.london.edu/rportes/DP4717.pdf.

24. For recountings of the battle between the competing approaches, see Gelpern \& Gulati, supra 
International Monetary Fund (IMF) Deputy Director Anne Krueger, called for the creation of an IMF-run bankruptcy court for sovereigns. ${ }^{25}$ The competing plan, introduced by John Taylor, Under Secretary for International Affairs at the U.S. Department of the Treasury, proposed inducing market participants to design contracts that would address concerns about moral hazard and bondholder coordination. ${ }^{26}$ The latter was the CAC solution. ${ }^{27}$

As noted, the debate centered around New York-law bonds, nearly all of which gave bondholders the individual right to opt out of a restructuring. Proponents of contract reform needed to explain why they knew better than the market, which apparently had rejected the use of CACs. ${ }^{28}$ The story that emerged, which we explore further below, was an historical one that combined several discrete ideas:

Bond lending poses unique coordination problems. In the 1970s and early 1980s, commercial-bank syndicates made most private loans to emerging-market sovereigns. ${ }^{29}$ These banks can coordinate their response to a financial crisis whether or not the loan contract says anything helpful on the subject. Commercial banks are relatively few in number, have close relationships with each other, and are vulnerable to arm-twisting by national regulators. Bondholders, by contrast, are widely dispersed, may have divergent interests, and are less subject to regulatory pressure. Bondholders are more likely to hold out from a restructuring in the hope of obtaining a better deal for themselves. Because holdouts can protract or derail a restructuring, bondholders should prefer, ex ante, contracts that allow a majority vote to bind dissenters as well. The puzzle was why New Yorklaw bonds lacked such terms.

Markets were not designing the right contracts. The second idea purported to solve the puzzle. Contracts are tools for managing risk. If New York-law bonds posed a risk that holdouts would disrupt a restructuring, one would expect lawyers to design contracts to solve the problem. Why was this not happening? Policymakers gradually settled on an explanation: because the bond markets had been dormant for so long, the lawyers involved in bond

note 6, at 1649-60; Portes, supra note 23; see also RODRIGO OLIVARES-CAMINAL, LEGAL ASPECTS OF Sovereign DebT Restructuring (2009); Mauro Meglioni, Sovereign Debt: GenesisRESTRUCTURING-LITIGATION (forthcoming 2013) (on file with authors).

25. See Anne O. Krueger \& Sean Hagan, Sovereign Workouts: An IMF Perspective, 6 CHI. J. INT'L L. 203 (2005); Sean Hagan, Designing a Legal Framework to Restructure Sovereign Debt, 36 GEO. J. INT’L L. 390 (2005).

26. See Gelpern \& Gulati, supra note 6, at 1639, 1653.

27. See id. (describing the speech and reactions to it).

28. See Eichengreen, supra note 10, at 86.

29. See Blaise Gadanecz, The Syndicated Loan Market: Structure, Development and Implications, BIS Q. REV., Dec. 2004, at 75, 75-76; see also Jill E. Fisch \& Caroline M. Gentile, Vultures or Vanguards: The Role of Litigation in Sovereign Debt Restructuring, 53 EMORY L.J. 1043, 1054 (2004) (describing the impetus for this trend in Latin America). 
deals did not recognize or know how to solve the collective-action concerns raised by bond lending. In fact, lawyers knew so little that they supposedly documented sovereign bond deals simply by copying terms from corporate bonds. ${ }^{30}$

Public actors could belp solve the problem. The story thus far is a simple tale of market failure. The third idea, then, was that public actors should intervene to help fix the market. For example, committees could design model contract terms, which regulators could pressure market participants to adopt. Once they saw the value of these terms, market participants would willingly adopt them in all contracts.

For policymakers, these ideas converged into a simple narrative: Bond lending posed new problems requiring new tools (i.e., CACs) to solve them, but the market was not innovating and needed help from the public sector. Once CACs were incorporated into sovereign bonds, private lenders would be more likely to participate in a sovereign debt restructuring. This trend would reduce the need for official intervention and give private lenders an incentive to lend more prudently.

If one accepts this story, there is little to be said against CACs. Who objects to prudent lending? But does the narrative hold up as an historical matter? Was the market unaware or unable to develop the CAC solution on its own, without official intervention?

Before we turn to the historical foundations of this narrative, we discuss how CACs assumed the prominence they enjoy today as policy tools. That story begins with Mexico's inclusion of CACs in its 2003 issuance of New York-law bonds.

\section{A. The Ascendance of CACs - Mexico, 2003}

Mexico's bond issue in February 2003 rendered the debate between bankruptcy and CAC solutions a thing of the past. Focusing only on collective modification clauses, Figure 1 shows how the vast New York market turned on a dime. Before 2003, only a handful of New York-law bonds included collective modification clauses. After 2003, these clauses appeared in nearly every issuance. ${ }^{31}$

30. For a description of the U.S. Treasury's efforts, and an explanation of such market practices, see Randal Quarles, Herding Cats: Collective Action Clauses in Sovereign Debt - The Genesis of the Project to Change Market Practice in 2001 through 2003, 73 LAW \& CONTEMP. PROBS. 29 (2010). For a discussion of some of the private-sector views on this and competing initiatives, see Robert B. Gray, Crisis Resolution: A Market-Based Approach, in COMMONwEAlth SECRETARiat, ECONOMIC PAPER No. 49, Enhancing Private CAPital Flows to Developing Countries in the NeW International Context 33 (Stephany Griffith-Jones, Amar Bhattacharya \& Andreas Antoniou eds., 2003).

31. For additional details, see Bradley \& Gulati, supra note 12; Weidemaier \& Gulati, supra note 8. 
Figure 1. Collective modification clauses in bonds governed by New York law.

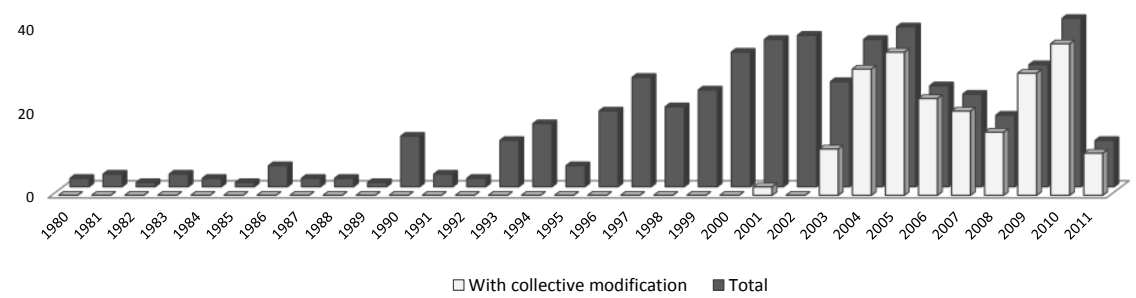

As we have explained, the pro-CAC historical narrative emerged to explain this transition and to justify the role of official-sector actors in promoting the switch. This narrative has several parts.

\section{New Problems Require New Solutions}

The first part of the Mexico story emphasizes the novelty of the collective-action problems posed by bond lending, and thus the novelty of CACs as a solution. Although the sovereign bond markets were vibrant throughout much of the nineteenth and early twentieth centuries, the Depression brought bond lending to an abrupt halt. Countries continued to issue bonds sporadically and in small amounts, but the market did not revive in earnest until the $1990 \mathrm{~s} .{ }^{32}$ In the intervening decades, sovereign lending primarily took the form of direct loans by governments, multilateral lenders such as the World Bank, or syndicates of commercial banks. $^{33}$ It was not until after the Brady Plan that the sovereign bond markets once again became the primary means of external sovereign borrowing. ${ }^{34}$

For these reasons, as the story goes, the lawyers responsible for documenting sovereign bond issues in the 1980s and 1990s were primarily familiar with commercial loans. Commercial banks have a relatively easy time coordinating their response to a sovereign's financial distress. 35 Thus,

32. For a discussion of the evolution of the sovereign bond markets, see Marc Flandreau, Juan Flores, Norbert Gaillard \& Sebastián Nieto-Parra, The End of Gatekeeping: Underwriters and the Quality of Sovereign Bond Markets 1815-2007 (Nat'l Bureau of Econ. Research, Working Paper No. 15128, 2009); Marc Flandreau, Norbert Gaillard \& Ugo Panizza, Conflicts of Interest, Reputation, and the Interwar Debt Crisis: Banksters or Bad Luck? (Graduate Inst. of Int'l \& Dev. Studies, HEID Working Paper No. 02/2010, 2010), available at $\mathrm{http}: / /$ ssrn.com/abstract_id=1588031.

33. See Gadanecz, supra note 29.

34. See Udaibir Das et al., Sovereign Debt Restructurings 1950-2010: Literature Survey, Data, and Stylized Facts 18 (Int'l Monetary Fund, Working Paper No. 12/203, 2012) ("The Brady Plan can . . . be seen as the start of modern-era sovereign bond trading.").

35. To be clear, we are recounting the general story, not stating an empirical fact. We do not wish to understate the difficulties involved in coordinating the response of commercial banks to sovereign financial crisis. See Richard Portes, The Role of Institutions for Collective Action, in MANAGING FinANCIAL AND CORPORATE Distress: Lessons From Asia 47, 63 (Charles Adams et al. eds., 
the lawyers were unfamiliar with the collective-action problems posed by bond lending. Because of their inexperience with sovereign bonds, lawyers (allegedly) based the new sovereign bond documents on the closest template they could find: cross-border corporate bonds. ${ }^{36}$ In the United States, the Trust Indenture Act ${ }^{37}$ forbids the use of collective modification clauses in corporate bonds. ${ }^{38}$ The architects of this prohibition viewed bankruptcy as the preferable alternative. ${ }^{39}$ For sovereigns, however, bankruptcy is not an available option. Had lawyers been more attentive to the need to provide for a coordinated workout process, they would have modified corporate bonds to make them suitable for sovereign borrowers. Alas, their inexperience with bond lending meant that they did little more than copy the corporate template.

We have described this story in other work, where we also explain why it is a flawed description of the contracts produced during this era. ${ }^{40}$ The story is important, however, because it provided CAC proponents with a justification for official-sector intervention in the bond markets. The story attributed the absence of CACs from the market for New York-law bonds to ignorance rather than investor preference. It also offered a basis for dismissing contrary evidence, such as the inconvenient fact that most English-law bonds drafted in the 1980s and 1990s did include CACs, as did a handful of New York-law bonds. ${ }^{41}$ According to the story, this too was the result of copying - only the lawyers involved had copied English-law corporate bonds, or sovereign bonds derived from that template. ${ }^{42}$ Because of legal differences between the markets, the English-law corporate template included CACs. ${ }^{43}$ By positing that lawyers neither anticipated bondholder-coordination problems nor designed contract terms to address them, the story provided a basis for government intervention.

2000).

36. See Weidemaier \& Gulati, supra note 8, (manuscript at 11-12).

37. 15 U.S.C. \$S 77 aaa-bbbb (2012).

38. Id. $\$ 77 \mathrm{ppp}$.

39. Mark J. Roe, The Voting Probibition in Bond Workouts, 97 YALE L.J. 232, 234 (1987).

40. See Weidemaier \& Gulati, supra note 8, (manuscript at 16-26).

41. See Weidemaier \& Gulati, supra note 8, (manuscript at 17) (discussing English law drafting practices); infra Part II.B.2.b (discussing early CACs in New York).

42. We discuss this story in more detail below. See infra Part II.B.2.b.

43. See Lee C. Buchheit \& G. Mitu Gulati, Sovereign Bonds and the Collective Will, 51 EMORY L.J. 1317, 1324-26 (2002). The copying story drew further support from the fact that English-law CACs might, in theory, allow a restructuring to proceed with the support of only a minority of bondholders. See Weidemaier \& Gulati, supra note 8, (manuscript at 22-23). To many observers, this feature made English-law CACs seem ill-suited for the sovereign context. See Group OF TEN, REPORT OF THE G10 WORKING GROUP ON CONTRACTUAL CLAUSES 3-4 (2002) [hereinafter G-10 REPORT], available at http://www.bis.org/publ/gten08.htm. 


\section{The Public Sector as a Driver of Innovation}

The typical CAC narrative highlights Mexico's 2003 issuance as the key turning point. ${ }^{44}$ Part of the story is that Mexico's status as a market leader was crucial to the shift in New York-law bonds. 45 As the story goes, however, even Mexico would not have moved without substantial involvement by the public sector.

One critical intervention took place in 1996, when a report commissioned by the G-10 countries, the so-called "Rey Report," recommended altering sovereign bonds to mitigate the collective-action concerns inherent in bond lending. ${ }^{46}$ The Rey Report precipitated a spate of articles, policy reports, and reform proposals, many of which were organized by public-sector actors. ${ }^{47}$ By late 2002, a G-10 committee of experts had produced a set of model CACs for issuers to adopt. Among these model CACs, a modification clause allowed holders of $75 \%$ of the debt to bind dissenting creditors to a restructuring, and an acceleration clause denied individual bondholders the right to accelerate the debt after a default and instead made the decision to accelerate a collective one that could be made by holders of $25 \%$ of the debt and reversed by a $50 \%$ vote. 48

More importantly, U.S. Treasury officials launched a behind-the-scenes campaign, exhorting, educating, and arm-twisting in an effort to promote the use of these or competing model CACs in sovereign bonds. ${ }^{49}$ When the market switched after Mexico's 2003 issuance, these events seemed to merge into a coherent narrative: the market, because of incomplete information, had failed to design contract terms appropriate to the new world of sovereign bond lending. An education initiative led by the public sector - involving seminars, meetings, academic papers, etc. - had

44. See, e.g., Eichengreen, supra note 10, at 87; MEGLIONI, supra note 24, at ch. 11; Sönke Häseler, Collective Action Clauses in International Sovereign Bond Contracts - Whence the Opposition, $23 \mathrm{~J}$. ECON. SuRvs. 882, 886-87 (2009).

45. This is because many market participants worried that CACs would raise their borrowing costs. The fear had some grounding in theory: if CACs reduce the need for bailouts and facilitate "private sector involvement" in debt restructuring, private lenders might price this risk into their loans. On the other hand, CACs might also reduce the cost associated with protracted restructuring negotiations, and this might lower borrowing costs. Without a test case, it was not clear that any country would risk adding CACs to their bonds. Moreover, the test case could not be a small country on the market periphery. No one would follow the lead of such a bit player. Only a market leader could prompt a widespread change in contracts. For a discussion of the first-mover and negativesignal stories, see Häseler, supra note 44, at 9-12.

46. See G-10 REPORT, supra note 43.

47. Examples of the genre include Barry Eichengreen \& Ashoka Mody, Would Collective Action Clauses Raise Borrowing Costs? An Update and Additional Results (World Bank, Working Paper No. 2363, 2000); Buchheit \& Gulati, supra note 43. For a general discussion of reform proposals, see Weidemaier \& Gulati, supra note 8, (manuscript at 9-12).

48. See G-10 REPORT, supra note 43 , at $10-13$.

49. See Gelpern \& Gulati, supra note 6, at 1670-71. 
overcome this failure, and market-driven innovation had taken over in early 2003. By late 2003, the vast majority of new sovereign bonds issued under New York law used CACs. The key players took victory laps. ${ }^{50}$

\section{B. Europe, 2013}

The historical narrative supporting CACs is more extensive and nuanced than we have captured in our brief discussion. In many ways, however, that is the point. Narratives are effective because they are compelling, or at least useful, rather than because they are true. And this simple narrative - CACs were a new solution to a new problem that few understood, and therefore markets had failed to adopt them — was useful. It gave policymakers something concrete that they could do to help solve a perceived problem. Much Eurozone debt, it turns out, derives from bonds that do not include CACs. ${ }^{51}$ When a new crisis emerged in Europe, and when taxpayers again revolted at the perceived cost of bailing out heavily indebted countries, CACs emerged as part of the solution. ${ }^{52}$

By the time of the Eurozone crisis, nearly a decade had passed since Mexico's 2003 issuance. Yet reformers again encountered the inconvenient fact that many sovereigns issued bonds without CACs. ${ }^{53}$ Once again, however, there was an explanation. Unlike the emerging-market bonds that prompted reform efforts in the 1990s and early 2000s, which were governed by New York law, much of the relevant European debt involves bonds governed by the issuing country's local law. ${ }^{54}$ The sovereign debt markets are notoriously segmented, 55 and the dividing line is the law that governs the issuance. ${ }^{56}$ Thus, perhaps CACs had simply not yet caught on

50. See TAYLOR, supra note 4, at 129-30; Quarles, supra note 30, at 29; Sergio J. Galvis \& Angel L. Saad, Collective Action Clauses: Recent Progress and Challenges Ahead, 35 GEO. J. INT’L L. 713 (2004).

51. See, e.g., Lee C. Buchheit \& Mitu Gulati, How to Restructure Greek Debt (May 7, 2010) (unpublished manuscript), available at http://ssrn.com/abstract=1603304.

52. See Anna Gelpern \& Mitu Gulati, The Wonder-Clause, 41 J. ComP. ECON. 367 (2013).

53. Id. at 367-77. Another inconvenient fact is that, as Greece's restructuring has shown, it turns out to be relatively easy to restructure local-law bonds even though they do not include CACs. This is because virtually all of these bonds are governed by the issuing country's law and can be restructured by changing that law. Greece, for example, changed its law to provide that a supermajority vote in favor of restructuring would bind every bondholder — in effect, retroactively inserting a CAC into the bonds. See Jeromin Zettelmeyer et al., The Greek Debt Restructuring: An Autopsy 11-12 (Peterson Inst. for Int'l Econ., Working Paper No. 2013-13-8, 2013), available at http://ssrn.com/abstract=2144932.

54. See Jeromin Zettelmeyer \& Mitu Gulati, In the Slipstream of the Greek Exchange, VoxEU, Mar. 5, 2012, http://www.voxeu.org/article/slipstream-greek-debt-exchange.

55. As just one sign of market segmentation, it has been asserted that drafters "slavishly follow" practices in their market. See Gray, supra note 30, at 36.

56. For a discussion of the typical correlations between choice of law and contract provisions in the New York and London markets in particular, see Lee C. Buchheit, Choice of Law Clauses and Regulatory Statutes, 15 INT'L FIN. L. REV. 11 (1996). This is why, according to the pro-CAC narrative, English-law bonds included CACs but New York-law bonds did not - the lawyers began by copying 
in the local-law market. In that case, the parallel to the New York-law market was obvious, and so was the solution. An expert committee formed for the purpose of developing a standardized CAC, and Eurozone leaders have mandated the use of this clause in all Eurozone bonds issued after $2012 . .^{57}$

In the following sections, we examine the historical narrative supporting these CAC initiatives. We feel obliged to repeat that we have no objection to CACs and even assume that they may facilitate restructuring in some cases. Nor do we dispute that the public sector played a key role in prompting the widespread use of these terms. But market participants did not need to be educated about CACs. These clauses have appeared in sovereign bonds for a very long time, but they have never been viewed as a necessary part of bond documentation, much less as a panacea for the macroeconomic problems arising from sovereign financial distress.

\section{NOTHING New UNDER THE SUN}

Because of the episodic, recurring nature of sovereign financial crises, the sovereign debt literature often draws lessons from history. ${ }^{58}$ We are especially interested in the historical study of contracts. Our data set includes approximately 2,700 sovereign bond contracts and disclosure documents drawn from a variety of sources and covering the period 18232012.59

different forms.

57. The Eurozone-wide mandate ensures that there will be no first-mover penalty. See supra note 45 and accompanying text. The leaders of wealthy Eurozone countries have also tried to placate irate taxpayers by suggesting that CACs will facilitate private sector involvement in debt restructurings. See Gelpern \& Gulati, supra note 52, at 374-77.

58. For a non-inclusive list of relevant examples from the sovereign debt literature, see Flandreau, Gaillard \& Panizza, supra note 32; Federico SturZenegGer \& Jeromin Zettelmeyer, DeBT DEFAUlTS AND LESSONS FROM A DECADE OF CRISES (2006); Rogoff \& Zettelmeyer, supra note 22; Barry Eichengreen, Historical Research on International Lending and Debt, 5 J. ECON. PERSP. 149, 162-65 (1991); The International DebT Crisis in Historical Perspective (Barry Eichengreen \& Peter H. Lindert eds., 1989); Barry Eichengreen \& Richard Portes, Debt and Default in the 1930s: Causes and Consequences, 30 Eur. ECON. Rev. 599 (1986); Charles Lipson, Standing GuARD: Protecting Foreign Capital in the Nineteenth and Twentieth Centuries (1985); Albert Fishlow, Lessons from the Past: Capital Markets During the 19th Century and the Interwar Period, 39 INT'L ORG. 383 (1985).

59. The appendix reports the 2,030 sovereign issues for which we have relatively complete information about bond terms, meaning one or more of the following documents: the full prospectus, a physical copy of the bond, or the loan contract between the issuer and the underwriting or managing banks. For some early sovereign issues, we could not locate one of these documents and relied instead on excerpts of bond terms published in the newspaper. We exclude this subset from the results reported in the text. 


\section{A. Description of the Data}

Conceptually, the data set has two parts, distinguished by our method of data collection. The first part extends from 1820 to roughly 1980. For that era, it is difficult to find a centralized source of bond documents. Stockexchange archives include prospectuses and other sales documents for bonds listed on that exchange. We visited the archives for the New York Stock Exchange at the Library of Congress and for the London Stock Exchange at Guildhall. We took digital images of sales documents in each of these archives.

Sales documents typically describe or reprint key bond terms. It is possible, however, that the underlying loan contract between the issuer and the underwriting banks also contained important terms. Moreover, not every sovereign bond issue was listed on an exchange. Thus, we gathered additional documents from the archives of major banks, including Rothschild, Barings, UBS, HSBC, as well as the J.P. Morgan archives at the Morgan Library \& Museum. We also visited other collections of sovereign bonds and sales documents, as well as some collections of personal papers from prominent bankers, at Columbia University, Cornell University, Duke University, Harvard Business School, the Origins of Value Museum at Yale University, and the Wertpapierwelt Museum of Historical Shares and Bonds. ${ }^{60}$

The second portion of our data set consists of documents gathered from public databases, which provide fairly comprehensive data on sovereign bonds issued between approximately 1980 and 2011. We primarily gathered data from Thomson One Banker, but we supplemented this research with data from Perfect Information. ${ }^{61}$ There are undoubtedly gaps in the data. With respect to pre-War bonds, for example, we have only a few offerings from the Amsterdam market of the early 1800s, and we probably under-sample bonds that were issued on the Paris market. Moreover, except for bonds issued by Eurozone countries, only a handful of bonds in the data set were issued in domestic currencies. Most were also issued under foreign law. This predominance of foreign currency and foreign law implies that the bonds in our data set were marketed primarily to foreign investors. So does the fact that we draw most of our modern bonds from pay databases. ${ }^{62}$

The Appendix provides more detailed description of the data set. Except where otherwise noted, we focus in this paper on bonds issued in

60. Where we could, we supplemented the materials with information from contemporaneous newspaper advertisements and investor reports.

61. Because of differences in search capability, we used Perfect Information to collect information on bonds that were guaranteed but not issued by sovereigns.

62. Domestic investors lending in local currency under local law are not likely to be as concerned about contract protections and may be unwilling to pay for access to copies of bond-contract terms. 
the London and New York markets. Those markets were the locus of reform efforts in the 1990s and 2000s and figure prominently in the proCAC narrative.

\section{B. A Contracts History of the Bond Markets}

As noted, explanations for the absence of CACs in New York-law bonds - and the puzzling fact that CACs were present in English-law bonds - stressed that lawyers did not understand the coordination problems inherent in sovereign bond lending or know how to design appropriate contracts. In the next sections, we explain how the historical record undermines this understanding.

We focus first on collective acceleration clauses. The modern pro-CAC narrative focuses almost exclusively on collective-modification rights. But acceleration rights also featured prominently in the reform debates of the 1990s and early 2000s. ${ }^{63}$ Their prominence in those debates is not surprising. In theory, contracts can address bondholder-coordination problems in many ways, even without allowing for collective modification. ${ }^{64}$ Collective acceleration clauses limit the power of holdouts to disrupt a restructuring through litigation. ${ }^{65}$ Sharing clauses remove the incentive to hold out by requiring a lender who receives a disproportionate payment to share the payment pro rata with other lenders. ${ }^{66}$ Trustee clauses serve a similar function by appointing a trustee to advance the interests of bondholders as a group. ${ }^{67}$ Other types of collective representation are also possible, such as clauses providing for the appointment of a bondholder committee to negotiate a debt restructuring with the issuer. ${ }^{68}$ All of these possible reforms were debated in the years before Mexico's 2003 issuance. ${ }^{69}$

Because of its myopic focus on collective modification, the modern pro-CAC narrative overlooks a great deal of historical context. As we explain, CACs - defined in the broader sense as clauses designed to remedy bondholder-coordination problems - have been around for nearly a century. The clauses never became a standard feature of bond

\footnotetext{
63. See G-10 REPORT, supra note 43 .

64. For a discussion of the potential value of collective modification clauses, see Lee C. Buchheit, Majority Action Clauses May Help Resolve Debt Crises, INT’L FIN. L. REV., Aug. 1998, at 13.

65. See G-10 REPORT, supra note 43, at 6, 13 .

66. See Lee C. Buchheit, Changing Bond Documentation: The Sharing Clause, INT'L FIN. L. REv., July 1998 , at 17.

67. See Lee C. Buchheit, The Collective Representation Clause, INT’L FIN. L. REV., Sept. 1998, at 9.

68. See id. at 11.

69. See, e.g., Group of Ten, The Resolution of Sovereign Liquidity Crises: A Report to the Ministers and Governors Prepared Under the Auspices of the Deputies 17, 44 , 58 (1996), available at http://www.bis.org/publ/gten03.pdf.
} 
contracts, however, and there is little evidence that market participants assigned them much value.

\section{Collective Acceleration Clauses in Earlier Eras of Bond Lending}

Collective acceleration clauses limit the ability of individual bondholders to demand full payment of principal after a default. If the issuer misses a payment, for example, bondholders as a group might be better off allowing it some time to get its financial footing and resume payments. Individual bondholders, however, may be quick to accelerate, and the collective impact of these individual decisions may leave them all worse off. A modern clause reads something like this:

If an event of default ... occurs and is continuing, the holders of at least $25 \%$ of the aggregate principal amount of the outstanding global bonds may... declare all the global bonds to be due and payable immediately.... The holders of $662 / 3 \%$ or more of the aggregate principal amount of the outstanding global bonds may rescind a declaration of acceleration if the event or events of default giving rise to the declaration have been cured or waived. ${ }^{70}$

In the run-up to Mexico, acceleration clauses were a major part of proposed contractual reforms to deal with collective-action problems. ${ }^{71} \mathrm{~A}$ well-designed clause, reformers claimed, could prevent holdout creditors from using litigation to deny a sovereign the "breathing room" needed to get its financial house in order. ${ }^{72}$ Of course, if litigation were really so disruptive, one might wonder why these clauses were not already in widespread use. The answer cannot be that clauses of this sort were unknown to the market. To the contrary, acceleration clauses almost exactly like the one reprinted above have appeared in sovereign bonds for nearly a century. A 1923 issuance in New York by the Kingdom of the Serbs, Croats, and Slovenes contained the following clause:

In case [of default] ... the Bankers shall, if requested so to do by a writing signed by the holders of twenty-five per cent $(25 \%)$ in amount of the bonds then outstanding, declare the principal of all the bonds then outstanding to be due and payable immediately .... $[\mathrm{H}]$ owever ... if within one year after such declaration the default on the part of the Government shall have been made good to the satisfaction of the Bankers, then ... the holders of a majority in amount of the Bonds then outstanding, by written notice to the

70. Prospectus Supplement, Federative Republic of Brazil 10.25\% Global BRL Bonds, p. S-27 (May 10, 2007).

71. See G-10 REPORT, supra note 43.

72. See id. 
Bankers, may waive such default and rescind and annul such declaration of maturity .... ${ }^{73}$

Our research turned up a number of clauses similar to this one. ${ }^{74}$ Focusing on the pre-World War II period, our data set includes 460 bonds issued between 1822 and 1945. Of these, twenty-three bonds include collective-acceleration provisions. These clauses began to appear in the late nineteenth century, although they are concentrated in the first few decades of the twentieth.

Modern sovereign bonds are often assumed to be boilerplate, ${ }^{75}$ but these early bonds varied in their use of collective acceleration clauses. For one thing, countries that used these terms did not use them in each issuance. ${ }^{76}$ We also see no evidence that the clauses can be attributed to a single entity, such as an investment bank. Indeed, bonds with collective acceleration clauses were underwritten by a number of different banks. Finally, and most importantly, the clauses did not follow a standard template. Sovereigns adopted different thresholds, ranging from $5 \%$ to $50 \% .{ }^{77}$ Other clauses allocated the acceleration decision to the lead bank in the underwriting syndicate or to the authenticating agent. ${ }^{78}$ In other cases, the bond also provided for a trustee to represent the interests of

73. Kingdom of the Serbs, Croats \& Slovenes, General Bond Listing Application, National External Goal Loan, Forty-Year Eight Per Cent. Secured External Gold Coupon Bonds, at 10-11 (Aug. 10, 1922).

74. See, e.g., Kingdom of Hungary, Listing Application, Hungarian Consolidated Municipal Loan, Twenty-Year 7\% Secured Sinking Fund Gold (Coupon) Bonds External Loan of 1926 (Sept. 21, 1927); Province of Upper Austria (Land Oberosterreich) (Republic of Austria), Listing Application, External Secured Sinking Fund Six and One-Half Per Cent. Gold Bonds (Apr. 16, 1928); City of Cordoba (Argentine Republic), Listing Application, Ten-Year 7\% External Sinking Fund Gold Bonds of 1927 (Mar. 16, 1928); Kingdom of Roumania Monopolies Institute, Loan Agreement, 7\% Guaranteed External Sinking Fund Gold Bonds Stabilization and Development Loan of 1929 (Feb. 1, 1929); Agreement between Province of Silesia, Republic of Poland and the First National Bank of Boston (June 1, 1928); State Mortgage Bank of Yugoslavia, Indenture and General Bond (Apr. 1, 1933); Conversion Office for German Foreign Debts (Konversionskasse Für Deutsche Auslandsschulden), Prospectus, 3\% Dollar Bonds (Mar. 8, 1937); Union of South Africa, Prospectus, External Loan Bonds of December 1, 1955 (Nov. 29, 1955); Union of South Africa, Prospectus, External Loan Bonds of December 1, 1958 (Dec. 2, 1958).

75. W. Mark C. Weidemaier, Disputing Boilerplate, 82 TEMP. L. REV. 1, 2 (2009).

76. Peru, for example, issued bonds in 1924 without collective acceleration clauses but included the clauses in bonds issued in 1927. Compare Republic of Peru, Listing Application, Sanitation Loan Series of 1924 (Dec. 12, 1924), with Republic of Peru, Listing Application, Secured 7\% Sinking Fund Gold Bonds (Sept. 15, 1927).

77. See, e.g., Chilean Consolidated Municipal Loan, Listing Application, Grace National Bank of New York Interim Receipts for Thirty-One Year 7\% External Sinking Fund Gold Bonds, Series A, 1929 (Feb. 3, 1930) (5\%); Republic of Bolivia, Listing Application, External Twenty-Five Year Secured Refunding Eight Per Cent. Sinking Fund Gold Coupon Bonds (May 23, 1923) (10\%; trustee administered); Department of Cauca Valley (Republic of Colombia) Listing Application, 7.5\% Bonds (Aug. 15, 1927) (50\%).

78. See Conversion Office for German Foreign Debts (Konversionskasse Für Deutsche Auslandsschulden), Prospectus, 3\% Dollar Bonds (Mar. 8, 1937). 
bondholders; in these bonds, the acceleration clause allowed a defined percentage of bondholders to force the trustee to declare a default. ${ }^{79}$ In this subset of bonds, some clauses also established a voting threshold that would allow bondholders to reverse the trustee's decision to accelerate; others were silent on the subject. 80

From all of this, it is clear that collective acceleration clauses have been part of the sovereign debt landscape for nearly a century. The clauses were hardly universal, but they appeared commonly enough, and in enough variety, that it seems plausible to infer that market participants were aware of the potential hazards of uncoordinated bondholder action and viewed collective acceleration clauses as one (but only one) possible solution. We find no indication in the historical record that the clauses were considered remarkable or that there was any difficulty in using them when necessary. 81 Yet there is equally little evidence that market participants viewed collective acceleration as a necessary part of a rational sovereign debt regime.

Indeed, reform projects at the time, such as the League of Nations project to design model terms for international financial contracts, were acutely aware of coordination problems among bondholders and banks. In 1939, the League's Committee for the Study of International Loan Contracts produced a report and model clauses designed to address coordination problems that might occur throughout a loan's life cycle from issuance through default. ${ }^{82}$ With respect to bond issuance, for example, the report lamented the recurrent pattern of "excessive and unco-ordinated lending" and the inability to rely on underwriting banks to ensure that the borrowing country's aggregate debt level remained

79. See, e.g., Saxon Public Works, Inc. (Aktiengesellschaft Sächsische Werke), Listing Application, 20-year Bonds (May 27, 1925) (guaranteed by Free State of Saxony); German Central Bank for Agriculture (Deutsch Rentenbank-Kreditanstalt), Listing Application, 7\% Gold Loan (Sept. 10-14, 1925).

80. Compare, e.g., Saxon Public Works, Inc. (Aktiengesellschaft Sächsische Werke), Listing Application, 20-year Bonds (May 27, 1925) (providing that trustee may accelerate and must accelerate upon a $25 \%$ vote; silent on reversal of acceleration), with German Central Bank for Agriculture (Deutsch Rentenbank-Kreditanstalt), Listing Application, 7\% Gold Loan (Sept. 10-14, 1925) (including same provision, except explicitly providing that trustee may waive default upon majority vote).

81. Neither press reports, nor the writings from the time, nor the disclosures on the bonds themselves suggest that the use of acceleration provisions was considered remarkable in any way. For general background on the League of Nations loans, see Yann Decorzant \& Juan H. Flores, Public Borrowing in Harsh Times: The League of Nations Loans Revisited (Universidad Carlos III de Madrid Working Papers in Econ. History, Working Paper No. 12-07, 2012) (discussing loans and making no mention of acceleration clauses), available at http://earchivo.uc3m.es/bitstream/10016/15594/1/wp\%2012-07.pdf.

82. Report of the Comm. for the Study of International Loan Contracts, League of Nations Doc. C.145M.93 1939. II.A. (1939) [hereinafter Report on Loan Contracts]. 
manageable.83 As a solution, the report proposed the appointment of a "small standing body of recognised financial experts" to opine on the wisdom of proposed loans. ${ }^{84}$

With respect to the representation of bondholder interests during the loan and after default, the report devoted extensive discussion to the use of trustees and to entities such as the Corporation of Foreign Bondholders (CFB) and the Foreign Bondholders Protective Council (FBPC). ${ }^{85}$ The Committee also made an additional proposal: the bond might designate a representative empowered to negotiate with the issuer after default and to issue a decision that would be "binding on all bondholders, either absolutely or if supported by a fixed proportion of the bondholders." 86 The representative could also initiate legal proceedings against the debtor, and the report proposed an arbitration mechanism for this purpose. ${ }^{87}$ Here, the report came closest to recommending the use of collective acceleration clauses. If legal proceedings were in the best interest of bondholders, but the representative failed to initiate them, there had to be a mechanism for overriding the representative's decision. At the same time, the report's authors could not imagine giving each individual bondholder the right to initiate litigation or arbitration. "Too many lawsuits would be a bad thing[,] ... unpleasant for the debtors [and] their Stock Exchange effects would be disastrous in the case of international loans." 88 As a solution, the report proposed that legal proceedings could be initiated only if approved by holders of $5 \%$ of the bonds in circulation. ${ }^{89}$

At no point, however, did the report explicitly recommend the use of collective acceleration clauses. This cannot be because the Committee was unfamiliar with them. Its members were major players in the sovereign

83. One problem, the report noted, was the absence of "machinery for the ... difficult task of co-ordinating different markets." Id. at 8 .

84. Id.

85. See id. at 19-21. For a discussion of the history of the CFB and FBPC generally, see Michael R. Adamson, The Failure of the Foreign Bondholders Protective Council Experiment, 1934-1940, 76 BUS. Hist. REV. 479 (2002); Barry Eichengreen \& Richard Portes, After the Deluge: Default, Negotiation, and Readjustment During the Interwar Years, in THE INTERNATIONAL DEBT CRISIS IN HiSTORICAL PERSPECTIVE 12 (Barry Eichengreen \& Peter H. Lindert eds., 1989).

86. Report on Loan Contracts, supra note 82, at 20. This proposal itself raised bondholder coordination problems, which the report took pains to discuss. For example, if a majority of bondholders had to approve a restructuring agreement negotiated by the representative, how to deal with the problem of indifferent or free-riding bondholders? Cf. id. at 33-34. The report proposed a rule that a restructuring proposal negotiated by the representative would become binding unless a specified percentage of bondholders - the report suggested $5 \%$ but had no firm view on the question - requested a meeting to vote on the proposal. Id. at 32-33.

87. Report on Loan Contracts, supra note 82, at 26-27, 32-33.

88. Id. at 33 .

89. Id. at 32-33. The report's draft arbitration clause contained a different threshold (holders of not less than $10 \%$ of the outstanding amount of bonds). Id. at 26 . 
debt world, including representatives from major banks, as well as government legal advisors, ${ }^{90}$ and our data indicate that collective acceleration clauses appeared with some frequency in the bond issues of the 1920s and 1930s. ${ }^{91}$ On the whole, the evidence suggests that neither reformers nor market participants viewed collective acceleration clauses as an essential term. To all appearances, these clauses were merely one of many possible means of addressing bondholder coordination problems, and not a particularly favored one.

In the post-War period, collective acceleration clauses became more common, though they still appeared in only a minority of bonds. As Table 1 shows, these clauses were reasonably common long before Mexico's 2003 issuance brought CACs into the limelight. After Mexico's issuance, however, collective acceleration provisions became widespread. Between 1995 and 2002 - roughly the era in which collective action clauses became a subject of debate - $27 \%$ of the bonds in our sample included collective-acceleration provisions. After Mexico's 2003 issuance, the rate of use of these clauses jumps significantly. In the post-2002 data, these clauses appear in two-thirds of the sample. Our data also reveal that these clauses became increasingly standardized. As a rough measure, we see at least eight different versions of the clause in use in the pre-World War II period. After 2002, bonds with collective acceleration clauses cohere around a standard requiring a $25 \%$ vote to accelerate.

TABLE 1.

$\begin{array}{cccc}\text { YEARS } & \text { BONDS } & \begin{array}{c}\text { With COLLECTIVE } \\ \text { ACCELERATION }\end{array} & \begin{array}{c}\text { PCT. OF } \\ \text { TOTAL }\end{array} \\ 1820-1944 & 460 & 23 & 5 \% \\ 1945-1954 & 34 & 0 & 0 \% \\ 1955-1964 & 79 & 15 & 19 \% \\ 1965-1974 & 59 & 4 & 7 \% \\ 1975-1984 & 118 & 9 & 8 \% \\ 1985-1994 & 259 & 40 & 15 \% \\ 1995-2002 & 433 & 118 & 27 \% \\ 2003-2011 & 591 & 374 & 63 \%\end{array}$

The reform debates of the 1990s did not introduce collective acceleration clauses to the sovereign debt markets. Nor was Mexico's 2003 issuance the first instance, although it did lead to their more widespread

90. Id. at $5-6$.

91. In our sample, $5 \%$ of pre-World War II bonds include these clauses, and most of these issues were concentrated in the first decades of the twentieth century. 
and uniform use. The long pedigree of these clauses undercuts the claim that market participants were unaware of bondholder collective-action problems and required instruction on how to draft clauses to tackle them. At the same time, the infrequent use of these clauses suggests that market participants did not view collective-acceleration rights as necessary (or helpful) in enabling bondholders to mount a coordinated response to default.

\section{Modification Clauses and Their Substitutes}

Modification clauses enable bondholders to approve a restructuring in a vote that binds even dissenting bondholders. It is clear that by the 1930s, if not earlier, reformers were aware that the ability to bind dissenters might come in handy. Recall that the League's Committee for the Study of International Loan Contracts suggested that bonds designate a bondholder representative with the power to negotiate a settlement "binding on all bondholders" - with or without a bondholder vote. 92 At the same time, however, market participants seemingly viewed the ability to bind dissenters as a minor detail. In this section, we first present evidence to support this claim. We also present evidence that undercuts some of the copying stories that underlie the pro-CAC narrative.

\section{a. The (Marginal) History of Modification Clauses}

Modification clauses, like collective acceleration clauses, have a long history in sovereign bonds. ${ }^{93}$ Until the 1980s, however, they made very rare appearances. The earliest example we have found is a 1922 Czech bond issue negotiated in consultation with the League of Nations. ${ }^{94}$ This significant issuance of bonds involved major underwriting banks acting in consultation with governments in creditor countries. ${ }^{95}$ The 1923 issuance of these bonds provided that, at a meeting to consider "any proposal which may be made to them by the Czechoslovak Government...., the decision of the holders of the majority in nominal value of Bonds present at such meeting, either in person or represented by proxy, shall be binding

92. Report on Loan Contracts, supra note 82, at 20, 32-34.

93. W. Mark C. Weidemaier, Producing Change in Sovereign Lending Practices, in SOVEREIGN FINANCING AND INTERNATIONAL LAW: THE UNCTAD PRINCIPLES ON RESPONSIBLE SOVEREIGN LENDING AND BORROWING (Carlos Esposito et al. eds., forthcoming 2013).

94. The League assisted in arranging reconstruction loans for a number of countries and cities that would otherwise have been global capital markets. These included Austria, Bulgaria, Estonia, Greece, Hungary, and the city of Danzig. For history on the League Loans, see Margaret Myers, The League Loans, 60 POL. SCI. Q. 492 (1945); Decorzant \& Flores, supra note 81, at 14-16. The Czech loans were not among the League Loans, but the Czech government requested that any disputes with the banks be arbitrated by the League of Nations. See id. at 20 n.20.

95. Decorzant \& Flores, supra note 81, at 14. 
upon all Bondholders...."96 The clause (reprinted in full in the Appendix) does not limit the range of permissible topics at the meeting and plainly appears to allow a binding vote on even a restructuring proposal.

The League's Committee for the Study of International Loan Contracts was fully aware of the Czech modification provision. Indeed, the Committee not only discussed the clause but mentioned one other sovereign bond that allowed collective modification: a bond issued as part of the Belgian Conversion Loan from 1936. ${ }^{97}$ In our data set of 460 preWorld War II bonds, however, no other bonds allow for collective modification. Indeed, we do not even find this clause in subsequent Czech bond issues. ${ }^{98}$ If there was a perception that bond documents should include a mechanism for binding dissenting creditors, it quickly waned.99 And there are some reasons why that might be the case. For one, as is clear from the League of Nations report on financial contracts, reformers researched and deliberated over the use of modification clauses but decided to focus their attention on other contractual devices, such as trustees and bondholder representatives. 100 It seems that market participants did too. In our data set, approximately $5 \%$ of pre-World War II bonds included collective acceleration clauses, and nearly 24\% (85/460) provided for a trustee to represent bondholder interests. ${ }^{101}$ In the run-up to Mexico's 2003 bond issue, this was also true of the debate over sovereign debt reform, which recognized that many contract terms could mitigate concerns over holdout creditors and help bondholders respond to

96. The Czechoslovak State, Listing Application, \$14,000,000 Eight Per Cent. Bonds (Jan. 11, 1923).

97. We found references to the Belgian Conversion Loan of 1936 in materials related to the Report of the Committee for the Study of International Loan Contracts, which we found in the League of Nations archives at the Peace Palace in Geneva, Switzerland. The materials discuss English corporate drafting practices (which reportedly included CACs at the time) and also refer to both the Czech and Belgian loans as the only examples of sovereign bonds to allow collective modification. The relevant parts are in two sections captioned Legal Questions Concerning International Loans (Oct. 1937) and Meetings of Bondholders Under English Law (Oct. 1937).

98. See, e.g., Czechoslovak Republic, Listing Application, Secured Gold Loan of 1925 (Nov. 18, 1925).

99. As Marc Flandreau has documented, London Stock Exchange (LSE) rules allowed a qualified majority of bondholders to override a dissenting minority when it came to the decision to allow a former defaulter to list securities on the Exchange. See Marc Flandreau, The London Stock Exchange and the Early Emergence of Sovereign Debt Collective Action Clauses in the 19th Century (18271868) (Nov. 4, 2012) (unpublished manuscript) (on file with authors). In that context, LSE rules effectively implemented a CAC-like regime even in the absence of relevant bond terms. Unlike the case with a modification clause, however, the underlying bond obligations remained unchanged (although the dissenters could do little to enforce the debt).

100. See Report on Loan Contracts, supra note 82, at 17-21, 32-37.

101. The trustee could not necessarily have committed bondholders to a restructuring, but it would have been empowered to represent bondholders in a wide range of contexts. See id. at 17-29. 
default collectively. ${ }^{102}$ Modification clauses featured more prominently in the modern debate, perhaps because modification clauses had become more widely used. ${ }^{103}$ Yet, modification clauses did not become the center of attention until the early 2000s.

During the interwar years, standing committees also played a much larger role in negotiating a settlement following default. ${ }^{104}$ The CFB played the dominant role in negotiating on behalf of British bondholders and, in the 1930s especially, the FBPC played a key role in negotiating on behalf of U.S. bondholders. ${ }^{105}$ Their negotiated settlements did not bind dissenting bondholders - and thus, did not address the problem that modification clauses are designed to solve - but the committees' recommendations in favor of a settlement held great weight. ${ }^{106}$

The belief that effective debt adjustment requires the participation of all bondholders seems to be a modern one. In the pre-War era, restructuring proposals were designed to encourage bondholder participation. The reason is obvious: the borrower could not materially reduce its payment obligations unless most bondholders agreed to reduce their claims. Typically, participating bondholders would exchange their bonds for new ones with reduced payment obligations or would tender their bonds to be stamped with a notice indicating they had assented to the restructuring offer. The disclosure documents accompanying the restructuring offer usually made clear that non-participating bondholders would not be paid. ${ }^{107}$ On some occasions, the issuer also promised not to give holdouts a better deal than it had given to participating bondholders. ${ }^{108}$ In most

102. See supra notes $24-27$ and accompanying text.

103. See infra Part II.B.2b.

104. See Eichengreen \& Portes, supra note 85, at 15; Eichengreen, supra note 58, at 162-65.

105. For a discussion of the complex relationship between the State Department and the FBPC, see Adamson, supra note 85.

106. See Eichengreen, supra note 58, at 163.

107. See, e.g., Republic of El Salvador, Listing Application, Certificates of Deposit for Customs First Lien Eight Percent Bonds (Mar. 22, 1937) (noting under the heading "Undeposited Bonds" that non-participating bondholders would not be paid and that, although "there is no intent ... to deprive [these] bondholders of their rights," most bondholders had elected to participate and the "first duty of the Republic... has clearly been to the ... bondholders who have cooperated"); Province of Buenos Aires, Argentine Republic, Loan Readjustment Plan of 1933, at 98 (Feb. 23, 1933) ("The Province does not propose to make any payments ... with respect to ... non-assenting bonds."); Republic of Panama, Listing Application, Thirty-Five Year 5\% Bonds (Dec. 4, 1933) (noting that "[b]ondholders who do not assent to the Plan are not assured" of receiving payments intended for participating bondholders).

108. Republic of Chile, Listing Application, Consolidated Municipal Loan (Aug. 22, 1939) (under the heading "Covenants," describing Chilean law providing that, if any outstanding bonds were to receive "conditions or treatment different" from that received by participating bondholders, all bonds would benefit from the better treatment); Republic of El Salvador, Listing Application, Certificates of Deposit for Customs First Lien Eight Percent Bonds (Mar. 22, 1937) (promising under the heading "Readjustment Agreement of April 27, 1936" that "the Republic will not pay a higher rate of interest or grant better terms ... to holders of bonds" not represented by the committee that had 
cases, however, the issuing country did not condition its restructuring offer on the assent of any particular number of bondholders - a fact that the disclosure documents accompanying the restructuring proposal often made quite clear. ${ }^{109}$ Even when a committee was appointed to represent holders of the restructured debt and was empowered to alter the terms of the restructuring, individual bondholders retained the right to opt out (reinstating their original claims) if they did not like the committee's decision. ${ }^{110}$ Instead of the all-or-nothing restructuring proposal envisioned by proponents of modification clauses, countries proposed restructuring terms to each bondholder.

From a modern perspective, this state of affairs seems unacceptable. In part, this perception reflects increased concern over the potential impact of holdout litigation on a sovereign's restructuring prospects. We return to that subject in the final section. For now, however, we simply emphasize that, as an historical matter, restructuring proposals made little effort to bind holdouts. ${ }^{111}$ Perhaps the most notable example of this indifference

negotiated the settlement); Republic of El Salvador, Listing Application, External Sinking Fund Dollar Bonds (Jan. 28, 1947) (promising under the heading "Offer of the Republic" that "[i]f the Republic shall hereafter grant to holders of any group of external bonds covered by the Offer terms more favorable than those contained herein ... it will extend ipso facto proportionately more favorable treatment to all the other holders of bonds covered by this Offer").

109. See, e.g., Province of Buenos Aires, Loan Readjustment Plan of 1933, at 98 (Feb. 23, 1933) ("This offer is not conditioned upon acceptance by any specified percentage of bonds ... and acceptance by any bondholder will make the Plan operative as to his assenting bond or bonds."). For similar examples, see Republic of Chile, Listing Application, External Sinking Fund Dollar Bonds of 1948 (Dec. 8, 1948); Republic of Colombia, Listing Application, 3\% External Bonds (June 24, 1941); The Department of Antioquia and Others, Listing Application, Sinking Fund Dollar Bonds (Dec. 7, 1949); Republic of El Salvador, Listing Application, External Sinking Fund Dollar Bonds (Jan. 28, 1947); Republic of Panama, Listing Application, Thirty-Five Year 5\% Bonds (Dec. 4, 1933); Republic of Uruguay, Listing Application, Readjustment Exchange Offer (Sept. 15, 1937); State of Hamburg, Listing Application, 4.5\% Dollar Bonds (Mar. 19, 1956). There are some exceptions. For example, a 1941 exchange offer by Panama became effective when accepted by more than $75 \%$ of bondholders (although 100\% acceptance was apparently required before the exchange bonds would be issued). See Republic of Panama, Listing Application, at 7 (May 16, 1941). In 1923, a proposed Mexican restructuring allowed a committee representing bondholders to declare the plan "operative as to any issue of Bonds at any time at which the Committee in its opinion shall deem a sufficient number of Bonds of such issue to have been deposited ...." United States of Mexico, Listing Application, (Readjustment of Debt) Deposit Receipts (Aug. 1, 1923).

110. See, e.g., United States of Mexico, Listing Application (Readjustment of Debt) Deposit Receipts (Aug. 1, 1923); Republic of El Salvador, Listing Application, Certificates of Deposit for Customs First Lien 8\% Bonds (Apr. 30, 1932).

111. As another example, some restructuring proposals appointed a committee to represent participating bondholders and gave the committee broad powers, including the power to modify the restructuring plan in ways that materially affected bondholders. This was consistent with the recommendations of the League of Nations Committee for the Study of International Loan Contracts, which had noted the potential benefits of bondholder representatives. The examples we uncovered, however, allowed individual bondholders to withdraw from the restructuring plan if they did not like the committee's decision. See, e.g., United States of Mexico, Listing Application, (Readjustment of Debt) Deposit Receipts (Aug. 1, 1923); Republic of El Salvador, Listing Application, Certificates of Deposit for Customs First Lien 8\% Bonds (Apr. 30, 1932); United States 
involves the 1922 Czech bonds, which contained the very first modification clause.

Given the economic and political upheaval of the ensuing decades, these bonds not surprisingly went into default. After World War II, the Czech government entered wide-ranging restructuring negotiations, including with the CFB and the FBPC. The FBPC archives at Stanford University include drafts of the restructuring agreements and related correspondence. Notwithstanding the modification clause in the underlying bonds - which, recall, allowed bondholders holding a majority in nominal value of the debt, voting at a meeting or by proxy, to approve "any proposal which may be made to them by the Czechoslovak Government" in a vote "binding upon all Bondholders" - we found no indication in the archives that any of the negotiating parties ever considered calling such a meeting or otherwise attempting to bind dissenters to a proposed restructuring. Every draft of the restructuring proposal envisioned that individual bondholders could assent to the plan by tendering their bonds to be stamped with notice of the restructuring. 112

Of course, the fact that holdouts were not viewed as a serious concern for much of the twentieth century does not mean they have not become problematic in the modern world, where sovereigns no longer enjoy absolute immunity from suit. ${ }^{113}$ It bears repeating, however, that modification clauses are but one way of addressing these concerns. Even if we assume that holdouts can sometimes present a material barrier to sovereign restructurings, it is not clear why modern reform efforts assign such priority to modification clauses. As we have explained, pro-CAC narratives typically justify reforms by positing that market participants have simply failed to understand the value of these clauses. But when we shift our gaze to the post-World War II era, it appears instead that market participants have been selectively employing modification clauses for some time.

\section{b. The Case of the (Not-so) Mistaken CACs in New York}

In the 1990 s and early 2000s, sovereign debt contracting practices raised two problems for proponents of CACs. First, most English-law bonds already had modification clauses. ${ }^{114}$ Second, although most New York-law bonds required unanimity, a handful of these bonds issued during the

of Mexico, Listing Application, (Readjustment of Debt) Deposit Receipts (Aug. 1, 1923).

112. See, e.g., Terms for Resumption of Service Proposed by Czechoslovak Gov't, Czechoslovak State Loan of 1922 (First Series and Series B) (1946).

113. For a discussion of the rise of holdout litigation in general, see Julian Schumacher, Christoph Trebesch \& Henrik Enderlein, Sovereign Defaults in Court: The Rise of Creditor Litigation 19762010 (Apr. 15, 2013), available at http://ssrn.com/abstract $=2189997$.

114. See Bradley \& Gulati, supra note 12. 
1980 s and 1990s included modification clauses. Recall that reform proposals were focused on the New York market. The ubiquity of modification clauses in the English-law market, and their occasional appearance in New York, suggested that the choice of unanimity was a deliberate one. ${ }^{115}$ For example, perhaps the New York-law market catered primarily to investors who preferred bonds that were harder to restructure. ${ }^{116}$ After all, issuers in the New York market tended to carry below-investment-grade ratings, whereas those in the English market tended to be above-investment grade. ${ }^{117}$ If many market participants did not like modification clauses, then arguments in favor of CACs including arguments made by one of us ${ }^{118}$ — were much harder to justify.

The copying stories we described earlier allowed reformers to dismiss the possibility that market participants were informed about CACs but sometimes preferred unanimity. The prevalence of modification clauses in English-law bonds was mere happenstance, an accidental byproduct of English corporate-bond contracts. ${ }^{119}$ Some also attributed the occasional use of modification clauses in New York-law bonds to copying. These bonds had been discovered by two researchers at the Reserve Bank of Australia, Mark Gugiatti and Anthony Richards. The issuers Kazakhstan, Lebanon, Bulgaria, Egypt, and Qatar - were relatively obscure and had been using modification clauses in their New York-law bonds since the late 1990s. ${ }^{120}$ In another case, the Thai government guaranteed a Thai power company's bond, which included a modification clause. ${ }^{121}$

Gugiatti and Richards concluded that modification clauses had been included in these bonds by accident. Their explanation posited that the lawyers who drafted these New York-law bonds inadvertently began with English-law forms. ${ }^{122}$ According to the story, the lawyers who drafted the bonds worked in the London offices of New York firms, and they simply

115. In theory, the unanimity requirement could have served multiple functions. For example, some investors may have preferred bonds that made restructuring harder, and these buyers may have dominated the New York-law market. Weidemaier \& Gulati, supra note 8.

116. $I d$.

117. Bradley \& Gulati, supra note 12.

118. Buchheit \& Gulati, supra note 43

119. E.g., Quarles, supra note 30; OLIVARES-CAMINAL, supra note 24; Eichengreen, supra note 10, at 84. We discuss these stories at length in Weidemaier \& Gulati, supra note 8.

120. Mark Gugiatti \& Anthony Richards, The Use of Collective Action Clauses in New York Law Bonds of Sovereign Issuers, 35 GEO. J. INT’L L. 815 (2004).

121. See Yan Liu, Collective Action Clauses in International Sovereign Bonds (May 12, 2002) (draft paper presented at IMF Seminar on Current Developments in Monetary and Financial Law), available at http://www.ieo-imf.org/external/np/leg/sem/2002/cdmfl/eng/liu.pdf (mentioning the Thai guaranteed bond).

122. Gugiatti \& Richards, supra note 120, at 826. See also NOURIEL ROUBINI \& BRAD SETSER, BAIL OUTS OR BAIL-INS: RESPONDING TO FINANCIAL CRISES IN EMERGING ECONOMIES $311 \mathrm{n} .1$ (2004) (repeating the inadvertent copying story from Gugiatti \& Richards); Häseler, supra note 44. 
began with the (wrong) forms that were familiar to them. ${ }^{123}$ Gugiatti and Richards raised the question "whether the lawyers involved were cognisant of the innovative nature of the legal terms being used."124 Their answer, although delicately phrased, was no: "[O] ur assessment is that [with one exception] the inclusion of CACs was not necessarily a deliberate decision and was perhaps even somewhat inadvertent." 125 For reformers, the story had clear implications, which Gugiatti and Richards spelled out: "[T]he marketplace has historically paid little or no attention to this particular aspect of bond contracts.... [T] he inclusion of CACs has simply not been an important decision variable for borrowers or investors." 126

This conclusion is undermined by our broader inquiry into twentiethcentury contracting practices. We have already discussed the relatively frequent use of trustees and the occasional use of collective acceleration clauses in pre-War bonds. Given these patterns, we are skeptical of the claim that market participants were unaware of CACs - defined broadly to include terms other than modification clauses. ${ }^{127}$ Moreover, our inquiry into the so-called "inadvertent" New York-law CACs suggests to us that these clauses were the product of deliberate choice.

The Indonesian 1983 and 1986 Bonds. ${ }^{128}$ All of the bonds uncovered by Gugiatti and Richards were issued in the late 1990s. ${ }^{129}$ We have uncovered modification clauses in at least two previous New York-law issuances (in addition to the Czech issuance, the New York tranche of which would also have been governed by New York law). These bonds were issued by Indonesia in 1983 and 1986, and, as we discuss below, their use of modification clauses probably cannot be attributed to copying from English forms.

We begin with a caveat. The sales documents for these bonds do not specify the vote required to change payment terms. Instead, they refer readers to the Fiscal Agency Agreement, which we have not located.

123. Gugiatti \& Richards, supra note 120, at 823.

124. Id. at $825-26$

125. Id. at 826 .

126. Id. at 827 . The Thai guaranteed bond was somewhat inconvenient for the story because it had been drafted by the Hong Kong office of a New York firm. The explanation given here was that this bond was somehow sui generis because it involved a co-guarantee from the International Bank for Reconstruction and Development. One of us heard this explanation in the context of a prior project where, along with Anna Gelpern, we interviewed almost all of the key participants in the CAC initiative in New York a decade ago. See Gelpern \& Gulati, supra note 6.

127. See also Anna Gelpern \& Mitu Gulati, Innovation After the Revolution: Sovereign Bond Contracts, 4 CAP. MARKETS L.J. 85 (2009) (expressing skepticism regarding the inadvertence claims based on interviews with some of the key players).

128. Republic of Indonesia, Prospectus, U.S. \$250,000,000, Floating Rate Notes Due 1993 (Sept. 22, 1983); Republic of Indonesia, Prospectus, U.S. \$300,000,000, Floating Rate Notes Due 2001 (Jan. 18, 1986).

129. The earliest issue was in 1997. See Gugiatti \& Richards, supra note 120, at 821 tbl.2. 
Theoretically, the Fiscal Agency Agreement could set a voting threshold of $100 \%$, but we doubt that this is the case. For one thing, as a structural and linguistic matter, this would be an unusual way to disclose that the bond's payment terms could not be modified. Moreover, when English-law bonds include modification clauses, the sales documents often refer to the underlying agency agreement for information about voting thresholds. By contrast, disclosure documents for New York-law bonds typically state the unanimity requirement directly or do not refer to the subject at all.

The modification clauses found (we assume) in these Indonesian bonds cannot easily be attributed to inadvertence. The issues were managed out of New York. The law firms involved were White \& Case, for the issuer, and Sullivan \& Cromwell, for the underwriters. The prospectus identifies Sullivan \& Cromwell's New York office as a participant in the bond issue. ${ }^{130}$ The prospectus references three White \& Case offices, New York, London, and Hong Kong. In theory, the bond template could have originated from White \& Case offices in London or Hong Kong. It is much more likely, however, that the form originated in Sullivan \& Cromwell's New York office. Typically, the underwriter's counsel provides the basic contract template. ${ }^{131}$ This practice is especially likely to be true of these Indonesian bonds, because Sullivan \& Cromwell has long been a major player in the sovereign market, whereas White \& Case has been a relatively minor one. ${ }^{132}$

If we are correct that these Indonesian bonds include modification clauses and that the contract template originated from Sullivan \& Cromwell's New York office, then it is hard to attribute these clauses to inadvertent copying of English-law forms. Lawyers at Sullivan \& Cromwell knew how to draft New York-law bonds and had plenty of forms at their disposal.

Lebanon in 1997. The first of the New York-law bonds that Gugiatti and Richards identified was issued in 1997, by Lebanon. ${ }^{133}$ The U.S. lawyers involved in this issue were based in New York. (Recall that the inadvertent copying story posits that the lawyers worked at the London office of a New York firm. ${ }^{134}$ ) Dewey Ballantine represented the underwriters, and Freshfields represented the issuer. ${ }^{135}$ Assuming standard practice, Dewey Ballantine would have controlled the deal template, both because it was counsel for the underwriters and because the issuance would be governed

130. Id.

131. See Mitu Gulati \& Robert Scott, The Three and a Half Minute Transaction: BOILERPLATE AND THE LIMITS OF CONTRACT DESIGN 29 (2013).

132. See Michael Bradley et al., Lawyers: Gatekeepers of the Sovereign Debt Market?, INT'L REV. L. \& ECON. (forthcoming 2014), available at http:/ /scholarship.law.duke.edu/faculty_scholarship/2712.

133. The Lebanese Republic, Offering Circular, U.S. $\$ 400,000,0008.625 \%$ Bonds (Oct. 29, 1997).

134. Gugiatti \& Richards, supra note 120 , at 823.

135. Freshfields is based in London. 
by New York law. The relevant Dewey Ballantine office was the New York office, not the London office. ${ }^{136}$

Despite this evidence, let us assume that these New York-law Lebanese bonds originated with English-law forms. The evidence suggests that the lawyers involved were engaged in design, not copying. Shortly after this first issuance, Lebanon issued a second bond governed by New York law. Once again, Dewey Ballantine was counsel for the underwriters. This time, however, the lawyers involved worked at Dewey Ballantine's London office. ${ }^{137}$ The lawyers had an English-law template near at hand, for Lebanon had issued English-law bonds only two years before, in 1995. Below, we reproduce the relevant modification language in Lebanon's 1995 English-law bonds and contrast that with the language in Lebanon's 1997 New York-law bonds. The emphasis is ours and reveals important differences.

Lebanon, July 25, 1995; \$300 million; 9.125\% Bonds due 2000 (English Law).

The Agency Agreement contains provisions for convening meetings of the Bondholders to consider any matter affecting their interests, including the modification by Extraordinary Resolution of these Conditions or the provisions of the Agency Agreement. The quorum at any meeting for passing an Extraordinary Resolution will be one or more persons present holding or representing a clear majority in principal amount of the bonds for the time being outstanding, or at any adjourned meeting one or more present whatever the principal amount of the Bonds held or represented by him or them, except that at any meeting the business of which includes the modification of certain of these Conditions the necessary quorum for passing an Extraordinary Resolution will be one or more persons present holding or representing no less than two-thirds, or at any adjourned meeting not less than one-third, of the principal amount of the Bonds for the time being outstanding. An Extraordinary Resolution passed at any meeting of the Bondholders will be binding on all Bondholders, whether or not they are present at the meeting, and on all Couponholders. ${ }^{138}$

Lebanon, Oct. 29, 1997; \$400 million; 8.625\% Bonds due 2007 (New York Law).

The Fiscal Agency Agreement contains provisions for convening meetings of Bondholders to consider any matter affecting their

136. A critic might say that this particular Lebanon bond offer was sui generis because it was backed by an International Bank for Reconstruction and Development guarantee (the same story that was told with respect to the Thai guaranteed bond).

137. The issuer's counsel was once again Freshfields.

138. The Lebanese Republic, Offering Circular, U.S. $\$ 300,000,0009.125$ per cent. Bonds, at 8 (July 25, 1995) (under the heading "Meetings of Bondholders and Modification"). 
interests, including the modification of these Conditions or the provisions of the Fiscal Agency Agreement, provided that no modification of the Conditions or the Fiscal Agency Agreement may be made without the consent or affirmative vote (by person or by proxy) of persons holding or representing no less than $75 \%$ in aggregate principal amount of Bonds then represented at the relevant meeting of Bondholders which would (i) change the due date for any amount payable by the Republic under the Bonds; (ii) reduce or cancel any portion of the principal amount of the Bonds or the amount of interest or any other amount payable under the Bonds or modify the rate of interest on the Bonds; (iii) modify the currency of payment under the Bonds; (iv) change the identity of any Person obligated under the Bonds or the release, in whole or in part, of any such Person; or (v) modify the provisions of the Conditions or the Fiscal Agency Agreement relating to the quorum required at any meeting of Bondholders or the percentage of Bondholders required to pass any resolution or otherwise modify the provisions summarized in this paragraph. A resolution duly passed in accordance with the provisions of the Fiscal Agency Agreement at any meeting of the Bondholders will be binding on all Bondholders whether or not they are present at the meeting and whether or not they vote in favor. ${ }^{139}$

It strikes us as difficult, by any stretch of imagination, to attribute these differences to inadvertence rather than design. The 1995 clause resembles the standard English-law modification clause of the period. ${ }^{140}$ It specifies diminishing quorum requirements where, at an adjourned meeting, a small minority of bondholders could potentially modify the bond's payment terms. By contrast, the New York-law bond issued in October 1997 establishes a higher voting threshold in which modifications must be approved by holders of $75 \%$ of the aggregate principal amount of the debt. The elevated voting threshold makes sense, as many U.S. investors viewed English modification requirements as too easily satisfied. ${ }^{141}$ In a letter to one of us, Lebanon's lawyers explained that they had deliberately sought to create a "hybrid" clause that "anticipat[ed] the need to restructure sovereign debt" without leaving open the possibility that a minority of bondholders could approve a restructuring (as in English-law bonds). ${ }^{142}$

139. The Lebanese Republic, Offering Circular, U.S. $\$ 400,000,0008.625$ per cent. Notes, at 11 (Oct. 29, 1997) (under the heading "Meetings of Bondholders; Modifications; Waiver").

140. See Bradley \& Gulati, supra note 12; Weidemaier \& Gulati, supra note 8.

141. See G-10 REPORT, supra note 43.

142. Letter from Louise Roman Bernstein at Dewey \& LeBoeuf to Mitu Gulati (July 17, 2008) (on file with authors). 
The Thai Guaranteed Bond of 1998. As noted, in 1998 the Kingdom of Thailand guaranteed a New York-law bond that contained a modification clause. The law firms involved included the Singapore and Thailand offices of White \& Case, the Hong Kong office of Cleary Gottlieb, and the Thailand office of Freshfields. Many practitioners in the official sector knew about this bond, and there was no obvious way to dismiss the bond as the product of inadvertent copying. Nevertheless, the fact that the bond was co-guaranteed by the International Bank of Reconstruction and Development implied that it might follow a different drafting template than bonds without official-sector guarantees. ${ }^{143}$

Our data set, however, includes one other guaranteed bond with a modification clause, and this one is not accompanied by an official-sector co-guarantee. Also issued in 1998, this New York-law bond was guaranteed by the Czech Republic and issued by a domestic airline, Aero Vodochody. ${ }^{144}$ And once again, White \& Case was one of the law firms involved, representing the underwriters out of its Prague office. ${ }^{145}$ We have no ready explanation for why modification clauses appeared in these (but only these) two guaranteed New York-law bonds, but the answer seems to involve experimentation by a particular law firm rather than the influence of official-sector co-guarantors. ${ }^{146}$

More generally, we see little evidence that these early New York-law modification clauses can be attributed to blind copying. The more plausible explanation seems to be that there were small issuers, operating at the margins and under the radar screen, for whom the standard New York-law template was unsatisfactory. And so they innovated. Whether other players in the New York market were capable of doing the same thing - or whether they required official-sector "help" — is another question.

143. See Electricity Generating Authority of Thailand, Offering Circular, $\$ 300$ million 7\% Guaranteed Bonds (Oct. 13, 1998); see also Gugiatti \& Richards, supra note 120, at 820 (noting the Thai bond and the guarantee).

144. See Aero Vodochody, Offering Circular, 7.5\% Guaranteed Notes Due 2005 (Nov. 10, 1998).

145. The issuer counsel was the Prague office of the U.S. firm, Altheimer \& Grey.

146. We also found modification provisions in issuances by one sub-sovereign in 1999: a bond issued by the Italian city of Florence under New York law. See City of Florence, Offering Circular (Apr. 29, 1999); City of Florence, Pricing Supplement (Oct 19, 1999). The modification clause in this bond cannot plausibly be attributed to drafter error or copying. The Florentine Offering Circular explicitly specifies both a unanimity provision and a non-unanimity modification provision, and states that subsequent pricing supplements should be understood to use the non-unanimity provision unless a particular supplement explicitly adopts the unanimity provision. $I d$. Terms and Conditions at $79-80$ (\$15(a) "Meetings requiring majority consent," and $\$ 15(\mathrm{~b})$ "Meetings requiring unanimous consent"). 


\section{WHAT'S OLD IS NEW AgAIN}

CACs may be a fine idea in many contexts. Public-sector actors may even play a salutary role in convincing market participants of the wisdom of including these terms in their contracts. We close, however, with a few cautionary notes about ongoing reform initiatives in the Eurozone and about contract-reform initiatives more generally.

\section{A. Euro-CACs, 2013}

After 2012, all Eurozone government securities with a maturity of more than one year will include standardized CACs - including modification clauses that allow a restructuring vote to be aggregated across multiple series of bonds. The rationale for this initiative neatly parallels the reason for the CAC initiative in New York a decade earlier. The bailout of Greece in 2010 resulted in intense political fallout, and CACs were invoked to ward off increasingly vocal critics. As was the case in the 1990s and 2000s, CACs were touted as a mechanism for replacing official-sector bailouts with private-sector involvement. ${ }^{147}$

One problem with the CAC initiative is that most Eurozone countries already use CACs in their foreign-law bonds. Reformers, however, point out that much of the debt stock in the Eurozone consists of local-law bonds, which (they assert) do not have CACs. ${ }^{148}$ Thus, when Greece restructured its local-law debt in March 2012, it did so by legislating the retroactive introduction of CACs into its bonds. ${ }^{149}$ Many viewed this as an objectionable and arbitrary act, far inferior to the orderly and equitable process that could be structured ex ante through the use of CACs. ${ }^{150}$ Once again, reform plans implicitly took the view that the market was failing to design optimal terms: if CACs were such a good idea, but local-law bonds did not use them, there must be a problem with the drafting process. As with reforms in the New York-law market, a high-level committee was created to draft model clauses. ${ }^{151}$ Eurozone leaders also decided to mandate use of the model clauses. That way, smaller issuers - such as countries like Slovenia - could adopt the clauses without fear that the market would interpret the use of CACs as a sign of higher risk of default.

Once again, however, our data complicate this picture. As noted, our data set consists primarily of bonds governed by foreign law. Thus, we do

147. Eurogroup Press Release, supra note 1.

148. See Gelpern \& Gulati, supra note 52, at 377.

149. See Zettelmeyer et al., supra note 53, at 7.

150. See Joseph Cotterill, A Proper Debt Restructuring, FT AlPHAVILlE (Mar. 16, 2012, 18:50), http:/ / ftalphaville.ft.com/2012/03/16/927231/a-proper-debt-restructuring/.

151. See EFC Sub-Committee on EU Sovereign Debt Markets, Model Collective Action Clause 2012, Common Terms of Reference (Feb. 17, 2012), available at http://europa.eu/efc/sub_committee/pdf/cac_-_text_model_cac.pdf. 
not have a large or plausibly representative sample of local-law issues. Nevertheless, those bonds we do have suggest that CACs have been sporadically included in local-law debt for many years. ${ }^{152}$ In the 1990 s, for example, several issues by the United Kingdom (1992 and 1996) included modification clauses of the sort commonly found in English-law debt. In a few other cases, sovereigns guaranteed local-law bonds with modification clauses. ${ }^{153}$ Then, after the CAC initiative in New York, the United Kingdom and Germany each included modification clauses in local-law bonds in an effort to provide a model for smaller, less-influential issuers to follow. $154 \mathrm{~A}$ number of smaller issuers have also used the clauses in recent years. These include Slovenia and St. Kitts \& Nevis, the latter of which recently completed a restructuring of local-law debt that turned out to include modification clauses. ${ }^{155}$

We cannot make broad claims about the prevalence of modification clauses in local-law bonds. We suspect that these clauses appear rarely. It is clear, however, that the clauses have been used, sometimes by small countries on the market periphery. If market participants objected to the use of CACs, or if lawyers were reluctant to implement them, we would not expect clauses to appear in these places. Of course, this begs the question: why do we not see more local-law issuers using CACs? We cannot answer this question, although it is possible that market participants have long (and correctly) viewed local-law bonds as relatively easy to restructure even without CACs. One way or the other, it is clear that local-law CACs are not a novel invention that had to be designed by a government-sponsored committee of experts. As was the case in New York, they were right there all along.

\section{B. CACs as the Latest Fashion in Contract Reform}

It is hard to construct a coherent picture from a century of contracting practices. Even one sovereign bond issuance is the product of multiple individuals operating within different institutions having different goals and incentives. As a result, we do not pretend to offer a complete explanation of the role CACs have served in the sovereign debt markets. We do, however, offer several observations about the prominence CACs have enjoyed in policy debates over the past several decades. And to be

152. Among sub-sovereign issuers, we have an example as early as 1963: the City of Milan.

153. These include a number of bonds guaranteed by the United Kingdom, Portugal, South Africa, and France. The French version of a CAC is a procedure known as masse.

154. This move by a number of the more prominent European issuers is described as part of the discussion of the 2003 CAC initiative in Gelpern \& Gulati, supra note 6, at 1674.

155. See Republic of Slovenia, Offering Circular, 4.375\% Notes Due 2021 (Jan. 17, 2011); Robin Wigglesworth, St. Kitts and Nevis Agree to Restructure Debts, FIN. TIMES (Mar. 18, 2012), http://www.ft.com/intl/cms/s/0/924e7bea-70f6-11e1-a7f1-00144feab49a.html\#axzz2AyVhaQoN. 
clear, despite the range of contract terms capable of addressing collectiveaction problems, ${ }^{156}$ the modern discussion of CACs has narrowed to focus largely on modification clauses.

First, the interest in reforming sovereign bond contracts is not new. ${ }^{157}$ Perhaps the major difference between modern and earlier reform initiatives is that modification clauses are now in vogue. Prior reforms focused on trustees and other mechanisms for allowing bondholders to monitor the issuer during the loan and respond to default. Even at the time, however, it appears that contract drafters were engaged in a fair amount of experimentation, from the rare use of collective acceleration clauses to the more frequent use of trustees ( $24 \%$ of our pre-War sample). Still, these clauses never entered widespread use, perhaps because officialsector actors never pushed hard to convince the market to adopt them. After all, the bond markets crashed during the Depression, and the task of reforming largely dormant markets may have seemed less urgent. Yet the long history of contract experimentation also implies that bond markets have a greater capacity to innovate than reformers often attribute to them. With respect to modification clauses in particular, we find it hard to believe that market participants did not know about these clauses. To the contrary, our analysis of early- and mid-twentieth century restructuring practices indicates that restructurings were not thought to depend on the ability to bind dissenters.

Of course, dissenters may now pose a greater threat. The obvious reason is the demise of the doctrine of absolute sovereign immunity and the rise of the modern vulture fund. ${ }^{158}$ Now that sovereigns can be sued - indeed, now that holdouts have achieved some rather spectacular (if perhaps temporary) victories 159 — perhaps CACs have become more important for limiting holdout litigation. ${ }^{160}$ But if so, this trend does not explain the focus on modification clauses over other contractual methods for addressing holdout concerns. Nor does it create a plausible link between CACs and the key official-sector justification for them, which is that CACs

156. See, e.g., supra text accompanying notes 70-73 (discussing collective acceleration clauses) and 92-113 (discussing modification clauses).

157. See supra text accompanying notes 82-89.

158. See Schumacher, Trebesch \& Enderlein, supra note 113.

159. For example, seizing an Argentinian naval vessel, Drew Benson, Bond Vigilantes' Ghana Ambush Proves Default Hex Unbroken, BLOOMBERG (Oct. 4, 2012), http://www.bloomberg.com/news/2012-10-04/bond-vigilantes-ghana-trap-shows-default-hexargentina-credit.html, and obtaining an injunction that may require Argentina to choose between paying holdouts or defaulting on its restructured debt, NML Capital Ltd. v. Republic of Argentina, 699 F.3d 246, 250 (2d Cir. 2012).

160. This assumes the clause is properly drafted. See Anna Gelpern, Sovereign Restructuring After NML v. Argentina: CACs Don't Make Pari Passu Go Away, Credit SliPs (May 3, 2012, 10:38 AM), http://www.creditslips.org/creditslips/2012/05/sovereign-restructuring-after-nml-v-argentina-cacsdont-make-pari-passu-go-away.html. 
help prevent bailouts. ${ }^{161}$ This claim has some theoretical backing. ${ }^{162}$ But it is absurd to suggest that recent bailouts - of Greece, say, or of Mexico in 1995 - had anything to do with the absence of CACs from the relevant bonds. ${ }^{163}$ CACs have become a talisman, invoked seemingly to imply that such small tokens can ward off the great problems associated with massive sovereign borrowing in interconnected global markets. ${ }^{164}$

The pro-CAC historical narrative abets this practice by suggesting that contract reform - something that official-sector actors can at least achieve - is beyond the capacity of market actors. To a degree, we share the belief that bond contracts may not contain the optimal set of terms. ${ }^{165}$ But a more accurate historical narrative begins by acknowledging that the bond markets exhibit more innovation than is often acknowledged. Likewise, we have found no case where official-sector actors have introduced a novel contract term into a bond market. If CACs are to be the centerpiece of a reform agenda, they should be defended on functional grounds rather than on contestable historical ones.

161. TAYLOR, supra note 4; Quarles, supra note 30.

162. See, e.g., Eichengreen, supra note 10, at 83-88.

163. See Gelpern \& Gulati, supra note 52, at 368-70.

164. As noted earlier, CACs appear to be the solution du jour. For example, we have also seen proposals to add collective action clauses to bonds issued by U.S. municipalities. See Remarks of James E. Spiotto, supra note 20.

165. See GULATI \& SCOTT, supra note 131 , at 177-78. 


\section{APPENDIX 1: 1923 CZECH BOND EXCERPT}

15. Should circumstances arise hereafter in which it may be necessary or expedient to obtain the sanction of the Bondholders to any exercise of their rights or their decision upon any proposal which may be made to them by The Czechoslovak Government, Messrs. Baring Brothers \& Co., Limited, and Messrs. Kidder, Peabody \& Co., shall be at liberty by publication in two London newspapers and two New York newspapers and two Amsterdam newspapers of an advertisement to convene a General Meeting of the Bondholders to be held in the City of London at a place and time and on a day to be prescribed in the advertisement, not being less than thirty days subsequently to the publication of the advertisement and the decision of the holders of the majority in nominal value of Bonds present at such meeting, either in person or represented by proxy, shall be binding upon all Bondholders, whether present at the meeting or not, but such majority must be comprised of not less than fifty per cent. of the Sterling Bonds and not less than fifty per cent. of the Dollar Bonds outstanding, and any meeting duly convened may appoint a Chairman and be adjourned from time to time by resolution of the majority of Bondholders present in person or by proxy. Messrs. Baring Brothers \& Co., Limited, and Messrs. Kidder, Peabody \& Co., and Messrs. Hope \& Co., may make such regulations as they may think fit for the temporary deposit of Bonds, issue of voting certificates, lodgment and verification of proxies. 
APPENDIX 2: DATASET

\begin{tabular}{|c|c|c|c|}
\hline Issuer & $\mathbf{N}$ & $\%$ Total & Dates of Issue \\
\hline Argentina & 84 & $4.1 \%$ & $\begin{array}{l}\text { 1884, 1887, 1888, 1905, } \\
\text { 1909, 1910, 1911, 1912, } \\
\text { 1914(3), 1915, 1924, } \\
\text { 1925(5), 1926(4), 1927(3), } \\
\text { 1935, 1937(2), 1939(2), } \\
\text { 1970(2), 1991, 1992, } \\
\text { 1993(6), 1994(9), } \\
\text { 1995(13), 1996(10), 1998, } \\
\text { 1999, 2000(6), 2001(2), } \\
\text { 2005, 2010 }\end{array}$ \\
\hline Belgium & 82 & $4.0 \%$ & $\begin{array}{l}\text { 1920(2), 1921, 1924, } \\
\text { 1925(2), 1926, 1937, } \\
\text { 1954(4), 1957, 1961, 1962, } \\
\text { 1983, 1985(3), 1986(4), } \\
\text { 1987, 1988, 1989(5), } \\
\text { 1990(5), 1991(6), 1992(2), } \\
\text { 1993(5), 1994(5), 1995(2), } \\
\text { 1996, 1997, 2001, 2002(2), } \\
\text { 2003, 2004, 2008(4), } \\
\text { 2009(7), 2010(8), 2011 }\end{array}$ \\
\hline Mexico & 74 & $3.6 \%$ & $\begin{array}{l}\text { 1895, 1899, 1903, 1908, } \\
\text { 1910, 1913(2), 1963(4), } \\
\text { 1966(2), 1972(4), 1973, } \\
\text { 1975, 1976, 1977, 1981(3), } \\
\text { 1982, 1988, 1990(10), } \\
\text { 1992, 1995(4), 1996(3), } \\
\text { 1997(3), 1998(2), 1999(7), } \\
\text { 2000(3), 2001(3), 2002, } \\
\text { 2003(2), 2004, 2005(2), } \\
\text { 2007, 2009, 2010(3), 2011 }\end{array}$ \\
\hline $\begin{array}{l}\text { Russia (including city \& } \\
\text { railroad bonds) }\end{array}$ & 74 & $3.6 \%$ & $\begin{array}{l}\text { 1822, 1859(2), 1866, 1867, } \\
\text { 1869(3), 1881, 1882, 1888, } \\
\text { 1889(4), 1890(4), 1891(2), } \\
\text { 1893(2), 1894(4), 1896, } \\
\text { 1899, 1900, 1901, 1902, } \\
\text { 1905, 1906(2), 1909(2), } \\
\text { 1910(5), 1911, 1912(4), } \\
\text { 1913(3), 1914(4), 1916(2), }\end{array}$ \\
\hline
\end{tabular}




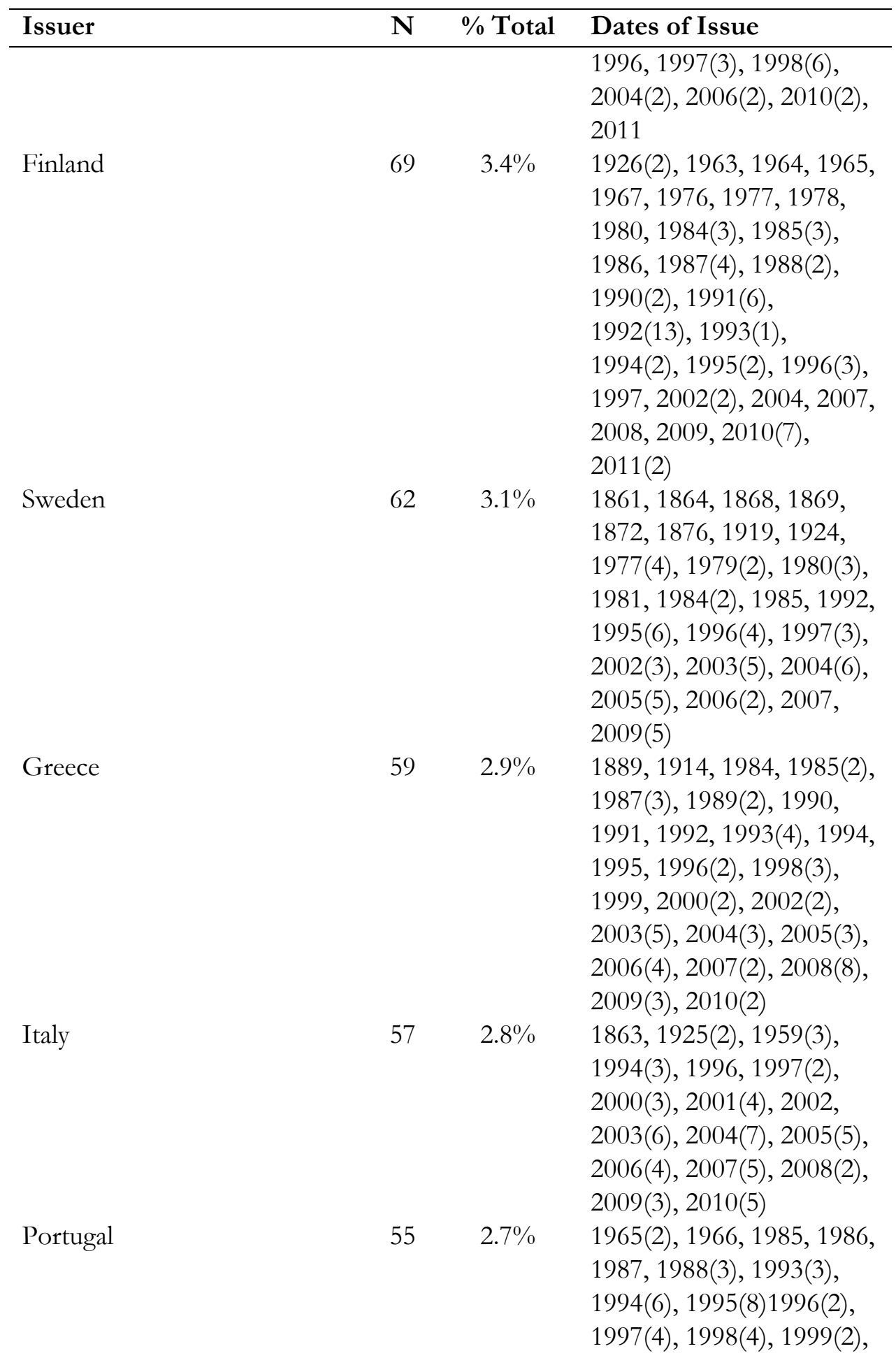




\begin{tabular}{|c|c|c|c|}
\hline Issuer & $\mathbf{N}$ & $\%$ Total & Dates of Issue \\
\hline & & & $\begin{array}{l}2000(2), 2002,2004 \\
2009(4), 2010(4), 2011(3)\end{array}$ \\
\hline Brazil & 54 & $2.7 \%$ & $\begin{array}{l}\text { 1883, 1905, 1922, 1927, } \\
\text { 1931(2), 1972(2), 1976(4), } \\
\text { 1977, 1978, 1980, 1995, } \\
\text { 1996(2), 1997, 1999, } \\
\text { 2000(2), 2003(2), 2004(4), } \\
\text { 2005(4), 2006(2), 2007(2), } \\
\text { 2008, 2009(4), 2010(8) }\end{array}$ \\
\hline United Kingdom & 13 & $0.6 \%$ & $\begin{array}{l}\text { 1916(2), 1917(2), 1978(2), } \\
\text { 1986, 1992(2), 1996, } \\
2003(2), 2006\end{array}$ \\
\hline France & 12 & $0.6 \%$ & $\begin{array}{l}\text { 1915, 1917, 1919, 1920, } \\
1921,1924(2), 1932(5)\end{array}$ \\
\hline Indonesia & 11 & $0.5 \%$ & $\begin{array}{l}\text { 1979, 1982, 1983, 1986, } \\
\text { 1996, 2004, 2005, 2008(4) }\end{array}$ \\
\hline Tunisie (Central Bank) & 10 & $0.5 \%$ & $\begin{array}{l}1995,1999,2000,2001, \\
2002(3), 2003(2), 2005\end{array}$ \\
\hline Germany & 9 & $0.4 \%$ & $\begin{array}{l}\text { 1924(2), 1930(3), 1937, } \\
1939,2005,2009\end{array}$ \\
\hline Israel & 9 & $0.4 \%$ & $\begin{array}{l}\text { 1989, 1993, 2000, 2003, } \\
2004(2), 2005,2006,2007\end{array}$ \\
\hline Oslo & 9 & $0.4 \%$ & $\begin{array}{l}\text { 1958(2), 1960, 1962, 1963, } \\
1967(2), 1970,1977\end{array}$ \\
\hline Dominican Republic & 8 & $0.4 \%$ & $\begin{array}{l}\text { 1922, 1924, 1926, 2001, } \\
\text { 2003, 2005, } 2010\end{array}$ \\
\hline Korea & 8 & $0.4 \%$ & $\begin{array}{l}\text { 1998(2), 2003, 2004, } \\
2005(2), 2009(2), 2010(3)\end{array}$ \\
\hline Latvia & 8 & $0.4 \%$ & $\begin{array}{l}\text { 1929, 1999(2), 2001, 2004, } \\
\text { 2008, 2011, } 2012\end{array}$ \\
\hline Romania & 8 & $0.4 \%$ & $\begin{array}{l}1922,1929,2000,2001 \\
2002,2003,2008,2010\end{array}$ \\
\hline Slovakia & 8 & $0.4 \%$ & $\begin{array}{l}1999(2), 2003,2004, \\
2007(2), 2009(2)\end{array}$ \\
\hline Trinidad \&Tobago & 8 & $0.4 \%$ & $\begin{array}{l}\text { 1984, 1992, 1993, 1994, } \\
1996,1999,2000,2007\end{array}$ \\
\hline Ukraine & 8 & $0.4 \%$ & $\begin{array}{l}2001,2002,2003(2), 2004 \\
2006,2007(2)\end{array}$ \\
\hline Barbados & 7 & $0.3 \%$ & 1990, 1994(2), 2000, 2001, \\
\hline
\end{tabular}




\begin{tabular}{|c|c|c|c|}
\hline Issuer & $\mathbf{N}$ & $\%$ Total & Dates of Issue \\
\hline & & & 2005,2006 \\
\hline Buenos Aires & 7 & $0.3 \%$ & $\begin{array}{l}\text { 1924, 1927(2), 1928(2), } \\
2010,2011\end{array}$ \\
\hline Pakistan & 7 & $0.3 \%$ & $\begin{array}{l}\text { 1994, 1997(2), 2004, } \\
2006(2), 2007\end{array}$ \\
\hline Qatar & 7 & $0.3 \%$ & $1999,2000,2009(5)$ \\
\hline Bolivia & 6 & $0.3 \%$ & $\begin{array}{l}1870,1871,1909,1922(2), \\
1924\end{array}$ \\
\hline Bulgaria & 6 & $0.3 \%$ & $1928,2001,2002(4)$ \\
\hline Thailand & 6 & $0.3 \%$ & $\begin{array}{l}\text { 1988, 1989, 1994, 1997, } \\
\text { 2004, } 2006\end{array}$ \\
\hline Belize & 5 & $0.2 \%$ & 2002(2), 2003, 2006, 2007 \\
\hline Cuba & 5 & $0.2 \%$ & $\begin{array}{l}\text { 1904, 1914, 1923, 1927, } \\
1937\end{array}$ \\
\hline Egypt & 5 & $0.2 \%$ & $2001(2), 2007,2010(2)$ \\
\hline $\begin{array}{l}\text { Norway (State Railroad - } \\
\text { Statsbaner) }\end{array}$ & 5 & $0.2 \%$ & $\begin{array}{l}\text { 1999, 2000, 2001, 2009, } \\
2010\end{array}$ \\
\hline Tanganyika & 5 & $0.2 \%$ & $\begin{array}{l}\text { 1931, 1932, 1950, 1953, } \\
1957\end{array}$ \\
\hline England & 4 & $0.2 \%$ & 1900(2), 1901, 1902 \\
\hline Guatemala & 4 & $0.2 \%$ & $1997,2001,2003,2004$ \\
\hline India & 4 & $0.2 \%$ & $1931,1932,1933(2)$ \\
\hline $\begin{array}{l}\text { Japan (Nippon T\&T Public } \\
\text { Corp) }\end{array}$ & 4 & $0.2 \%$ & 1963(2), 1977(2) \\
\hline Morocco & 4 & $0.2 \%$ & $1999,2003,2007,2010$ \\
\hline Slovenia & 4 & $0.2 \%$ & $1999,2000,2001,2007$ \\
\hline Australia (Sydney) & 3 & $0.1 \%$ & 1943, 1946, 1939 \\
\hline Belarus & 3 & $0.1 \%$ & 2010(2), 2011 \\
\hline Berlin & 3 & $0.1 \%$ & $1927,1957(2)$ \\
\hline Ceylon & 3 & $0.1 \%$ & 1930(2), 1935 \\
\hline Cuba (Banco Central) & 3 & $0.1 \%$ & $2008(3)$ \\
\hline Dubai & 3 & $0.1 \%$ & 2010(2), 2011 \\
\hline Dutch East Indies & 3 & $0.1 \%$ & 1922(2), 1923 \\
\hline Ecuador & 3 & $0.1 \%$ & $2000(2), 2005$ \\
\hline $\begin{array}{l}\text { European Coal and Steel } \\
\text { Community }\end{array}$ & 3 & $0.1 \%$ & 1962, 1975, 1977 \\
\hline European Investment Bank & 3 & $0.1 \%$ & $1976(2), 1977$ \\
\hline
\end{tabular}




\begin{tabular}{|c|c|c|c|}
\hline Issuer & $\mathbf{N}$ & $\%$ Total & Dates of Issue \\
\hline Kazakhstan & 3 & $0.1 \%$ & $1996,1997,2000$ \\
\hline Korea (Development Bank) & 3 & $0.1 \%$ & $2010(3)$ \\
\hline Northern Rhodesia & 3 & $0.1 \%$ & $1932,1933,1949$ \\
\hline Salvador & 3 & $0.1 \%$ & 1899, 1922, 1923 \\
\hline Serbia & 3 & $0.1 \%$ & $1881,2005(2)$ \\
\hline Seychelles & 3 & $0.1 \%$ & 2006, 2007, 2009 \\
\hline Southern Rhodesia & 3 & $0.1 \%$ & $1933,1948(2)$ \\
\hline Switzerland & 3 & $0.1 \%$ & $1919,1923,1924$ \\
\hline Abu Dhabi & 2 & $0.1 \%$ & 2007,2009 \\
\hline Albania & 2 & $0.1 \%$ & 1995,2010 \\
\hline Aruba & 2 & $0.1 \%$ & 2005,2006 \\
\hline Bahamas & 2 & $0.1 \%$ & 2003,2008 \\
\hline Bahrain & 2 & $0.1 \%$ & 2003,2010 \\
\hline Bosnia & 2 & $0.1 \%$ & 1997(2) \\
\hline Brazil (Sao Paulo) & 2 & $0.1 \%$ & 1925,1926 \\
\hline British Guiana & 2 & $0.1 \%$ & 1942,1949 \\
\hline Congo & 2 & $0.1 \%$ & 1993,2008 \\
\hline Cordoba (Argentina) & 2 & $0.1 \%$ & 1906,1928 \\
\hline Danzig & 2 & $0.1 \%$ & 1925 \\
\hline Estonia & 2 & $0.1 \%$ & 1927,2002 \\
\hline $\begin{array}{l}\text { European Economic } \\
\text { Community }\end{array}$ & 2 & $0.1 \%$ & 1976,1977 \\
\hline Georgia & 2 & $0.1 \%$ & 2007,2011 \\
\hline Germany (Berlin) & 2 & $0.1 \%$ & 1942,1925 \\
\hline Germany/Prussia & 2 & $0.1 \%$ & 1937,1940 \\
\hline Grand Russian Railway Co. & 2 & $0.1 \%$ & 1857,1861 \\
\hline Grenada & 2 & $0.1 \%$ & 2002,2005 \\
\hline Hamburg & 2 & $0.1 \%$ & 1926,1956 \\
\hline Helsinki & 2 & $0.1 \%$ & 1965,1992 \\
\hline Honduras & 2 & $0.1 \%$ & 1870,1913 \\
\hline Hong Kong & 2 & $0.1 \%$ & 2004,2004 \\
\hline Iran (Central Bank) & 2 & $0.1 \%$ & $2002(2)$ \\
\hline Iraq & 2 & $0.1 \%$ & 1937,2005 \\
\hline Kenya & 2 & $0.1 \%$ & 1933,1952 \\
\hline Liberia & 2 & $0.1 \%$ & 1898,1912 \\
\hline Luxembourg & 2 & $0.1 \%$ & 2008,2010 \\
\hline
\end{tabular}




\begin{tabular}{|c|c|c|c|}
\hline Issuer & $\mathbf{N}$ & $\%$ Total & Dates of Issue \\
\hline Macedonia & 2 & $0.1 \%$ & 2005,2009 \\
\hline Manitoba & 2 & $0.1 \%$ & 1908,1920 \\
\hline Mauritius & 2 & $0.1 \%$ & 1932,1995 \\
\hline Milan & 2 & $0.1 \%$ & 1963(2) \\
\hline Moldova & 2 & $0.1 \%$ & 1996,2002 \\
\hline Montenegro & 2 & $0.1 \%$ & 2010,2011 \\
\hline Netherlands & 2 & $0.1 \%$ & 1922,1947 \\
\hline New South Wales & 2 & $0.1 \%$ & 1937(2) \\
\hline Roumania & 2 & $0.1 \%$ & 1923,1937 \\
\hline Senegal & 2 & $0.1 \%$ & 2009,2011 \\
\hline Siam & 2 & $0.1 \%$ & 1905,1922 \\
\hline Sierra Leone & 2 & $0.1 \%$ & 1937,1938 \\
\hline South Africa (Johannesburg) & 2 & $0.1 \%$ & 1937,1938 \\
\hline Sri Lanka & 2 & $0.1 \%$ & 1997,2007 \\
\hline Tokyo & 2 & $0.1 \%$ & 1912,1965 \\
\hline Trinidad & 2 & $0.1 \%$ & 1933,1948 \\
\hline Tucuman & 2 & $0.1 \%$ & 1888,1899 \\
\hline Uganda & 2 & $0.1 \%$ & 1932,1933 \\
\hline Akershus (Norway) & 1 & $<0.1 \%$ & 1928 \\
\hline Amsterdam & 1 & $<0.1 \%$ & 1958 \\
\hline Antioquia (Colombia) & 1 & $<0.1 \%$ & 1949 \\
\hline Antwerp & 1 & $<0.1 \%$ & 1929 \\
\hline $\begin{array}{l}\text { Argentina (Buenos Aires } \\
\text { Province) }\end{array}$ & 1 & $<0.1 \%$ & 1910 \\
\hline Argentina (San Juan Province) & 1 & $<0.1 \%$ & 1909 \\
\hline Australia (Hobart) & 1 & $<0.1 \%$ & 1933 \\
\hline Australia (New South Wales) & 1 & $<0.1 \%$ & 1946 \\
\hline BA Water Supply & 1 & $<0.1 \%$ & 1890 \\
\hline Bavaria & 1 & $<0.1 \%$ & 1956 \\
\hline Belgian Congo & 1 & $<0.1 \%$ & 1958 \\
\hline Bergen & 1 & $<0.1 \%$ & 1964 \\
\hline Bergen (Norway) & 1 & $<0.1 \%$ & 1924 \\
\hline Berlin Electric & 1 & $<0.1 \%$ & 1930 \\
\hline Botswana & 1 & $<0.1 \%$ & 2003 \\
\hline Brazil (Rio Grande do Sul) & 1 & $<0.1 \%$ & 1927 \\
\hline Brazil (Western of Minas & 1 & $<0.1 \%$ & 1893 \\
\hline
\end{tabular}




\begin{tabular}{|c|c|c|c|}
\hline Issuer & $\mathbf{N}$ & $\%$ Total & Dates of Issue \\
\hline \multicolumn{4}{|l|}{ Railroad Co.) } \\
\hline Caldas (Colombia) & 1 & $<0.1 \%$ & 1949 \\
\hline Canada (Alberta) & 1 & $<0.1 \%$ & 1932 \\
\hline Canada (British Columbia) & 1 & $<0.1 \%$ & 1932 \\
\hline Canada (Newfoundland) & 1 & $<0.1 \%$ & 1933 \\
\hline $\begin{array}{l}\text { Chilean consolidated } \\
\text { municipal loan }\end{array}$ & 1 & $<0.1 \%$ & 1930 \\
\hline China (Bank of China) & 1 & $<0.1 \%$ & 1985 \\
\hline $\begin{array}{l}\text { China (Banque Industrielle de } \\
\text { Chine) }\end{array}$ & 1 & $<0.1 \%$ & 1913 \\
\hline $\begin{array}{l}\text { China (Bd of Posts and } \\
\text { Communications) }\end{array}$ & 1 & $<0.1 \%$ & 1908 \\
\hline China (Canton/Kowloon RR) & 1 & $<0.1 \%$ & 1907 \\
\hline $\begin{array}{l}\text { China (China Development } \\
\text { Bank) }\end{array}$ & 1 & $<0.1 \%$ & 2004 \\
\hline $\begin{array}{l}\text { China (Chinese Imperial } \\
\text { Railway) }\end{array}$ & 1 & $<0.1 \%$ & 1899 \\
\hline China (Honan RR) & 1 & $<0.1 \%$ & 1905 \\
\hline $\begin{array}{l}\text { China (Shanghai/Nanking } \\
\text { RR) }\end{array}$ & 1 & $<0.1 \%$ & 1907 \\
\hline $\begin{array}{l}\text { China (Tientsin/Chinkiang } \\
\text { RR) }\end{array}$ & 1 & $<0.1 \%$ & 1899 \\
\hline $\begin{array}{l}\text { China (Tientsin/Pukow } \\
\text { Railway) }\end{array}$ & 1 & $<0.1 \%$ & 1908 \\
\hline China (Tientsin-Pukow RR) & 1 & $<0.1 \%$ & 1908 \\
\hline Cologne & 1 & $<0.1 \%$ & 1957 \\
\hline Colombia (Antioquia) & 1 & $<0.1 \%$ & 1925 \\
\hline Colombia (Caldas) & 1 & $<0.1 \%$ & 1926 \\
\hline Colombia (Cundinamarca) & 1 & $<0.1 \%$ & 1926 \\
\hline Columbia (Cauca Valley) & 1 & $<0.1 \%$ & 1927 \\
\hline Columbia (Tolima) & 1 & $<0.1 \%$ & 1928 \\
\hline Copenhagen & 1 & $<0.1 \%$ & 1963 \\
\hline Cordova (argentina) & 1 & $<0.1 \%$ & 1899 \\
\hline Cundinamarca (Colombia) & 1 & $<0.1 \%$ & 1949 \\
\hline Czech (Carlsbad) & 1 & $<0.1 \%$ & 1924 \\
\hline Czech (Prague) & 1 & $<0.1 \%$ & 1922 \\
\hline Danzig Port & 1 & $<0.1 \%$ & 1927 \\
\hline
\end{tabular}




\begin{tabular}{|c|c|c|c|}
\hline Issuer & $\mathbf{N}$ & $\%$ Total & Dates of Issue \\
\hline $\begin{array}{l}\text { Denmark (Consolidated } \\
\text { Municipalities) }\end{array}$ & 1 & $<0.1 \%$ & 1921 \\
\hline Dominica & 1 & $<0.1 \%$ & 1963 \\
\hline Dubai (Dubai Global Sukuk) & 1 & $<0.1 \%$ & 2004 \\
\hline Fed. Malay States & 1 & $<0.1 \%$ & 1934 \\
\hline Fiji & 1 & $<0.1 \%$ & 2011 \\
\hline Finland (Municipalities) & 1 & $<0.1 \%$ & 1924 \\
\hline $\begin{array}{l}\text { France (Credit Foncier de } \\
\text { France) }\end{array}$ & 1 & $<0.1 \%$ & 1959 \\
\hline France (Electricite de France) & 1 & $<0.1 \%$ & 1977 \\
\hline Gabon & 1 & $<0.1 \%$ & 2007 \\
\hline $\begin{array}{l}\text { Germany (Central Bank of } \\
\text { Agriculture) }\end{array}$ & 1 & $<0.1 \%$ & 1925 \\
\hline Germany (Saxon Pub. Works) & 1 & $<0.1 \%$ & 1925 \\
\hline Ghana & 1 & $<0.1 \%$ & 2007 \\
\hline Gold Coast & 1 & $<0.1 \%$ & 1931 \\
\hline Haiti & 1 & $<0.1 \%$ & 1922 \\
\hline Isle of Man & 1 & $<0.1 \%$ & 1933 \\
\hline Ivory Coast & 1 & $<0.1 \%$ & 2010 \\
\hline Japan (Export-Import Bank) & 1 & $<0.1 \%$ & 1996 \\
\hline Japan (Industrial Bank) & 1 & $<0.1 \%$ & 1924 \\
\hline $\begin{array}{l}\text { Japan (Oriental Development } \\
\text { Co.) }\end{array}$ & 1 & $<0.1 \%$ & 1923 \\
\hline $\begin{array}{l}\text { Japan (South Manchurian RY } \\
\text { Ltd) }\end{array}$ & 1 & $<0.1 \%$ & 1908 \\
\hline Johannesburg & 1 & $<0.1 \%$ & 1937 \\
\hline Jordan & 1 & $<0.1 \%$ & 2010 \\
\hline $\begin{array}{l}\text { Kingdom of the Serbs, Croats } \\
\text { \& Slovenes }\end{array}$ & 1 & $<0.1 \%$ & 1922 \\
\hline Lebanon (IBRD guarantee) & 1 & $<0.1 \%$ & 1997 \\
\hline Louisiana & 1 & $<0.1 \%$ & 1914 \\
\hline Malaya & 1 & $<0.1 \%$ & 1949 \\
\hline Medellin (Colombia) & 1 & $<0.1 \%$ & 1949 \\
\hline $\begin{array}{l}\text { Mexico (Mexican National } \\
\text { Packing Co.) }\end{array}$ & 1 & $<0.1 \%$ & 1907 \\
\hline Micronesia & 1 & $<0.1 \%$ & 1993 \\
\hline Mongolia (Dev. Bank) & 1 & $<0.1 \%$ & 2008 \\
\hline
\end{tabular}




\begin{tabular}{|c|c|c|c|}
\hline Issuer & $\mathbf{N}$ & $\%$ Total & Dates of Issue \\
\hline Montevideo (Uruguay) & 1 & $<0.1 \%$ & 1922 \\
\hline Nairobi & 1 & $<0.1 \%$ & 1949 \\
\hline New Zealand (Dunedin) & 1 & $<0.1 \%$ & 1933 \\
\hline $\begin{array}{l}\text { New Zealand (New } \\
\text { Plymouth) }\end{array}$ & 1 & $<0.1 \%$ & 1933 \\
\hline New Zealand (Wanganui) & 1 & $<0.1 \%$ & 1932 \\
\hline Nicaragua & 1 & $<0.1 \%$ & 1895 \\
\hline Nigeria & 1 & $<0.1 \%$ & 2011 \\
\hline Northern Ireland & 1 & $<0.1 \%$ & 1939 \\
\hline Nova Scotia & 1 & $<0.1 \%$ & 1971 \\
\hline Nuremberg & 1 & $<0.1 \%$ & 1957 \\
\hline Nyasaland & 1 & $<0.1 \%$ & 1932 \\
\hline Oman & 1 & $<0.1 \%$ & 1997 \\
\hline Oxaca (Mexico) & 1 & $<0.1 \%$ & 1910 \\
\hline Palestine & 1 & $<0.1 \%$ & 1942 \\
\hline Paraguay & 1 & $<0.1 \%$ & 1871 \\
\hline Poyais & 1 & $<0.1 \%$ & 1823 \\
\hline Province of Upper Austria & 1 & $<0.1 \%$ & 1928 \\
\hline Queensland & 1 & $<0.1 \%$ & 1890 \\
\hline Rhodesia & 1 & $<0.1 \%$ & 1958 \\
\hline Rosario & 1 & $<0.1 \%$ & 1900 \\
\hline Rotterdam (Netherlands) & 1 & $<0.1 \%$ & 1924 \\
\hline Saarbruecken (Germany) & 1 & $<0.1 \%$ & 1927 \\
\hline San Paulo & 1 & $<0.1 \%$ & 1909 \\
\hline Santa Fe (Argentina) & 1 & $<0.1 \%$ & 1883 \\
\hline Silesia & 1 & $<0.1 \%$ & 1928 \\
\hline South Africa (Cape Town) & 1 & $<0.1 \%$ & 1937 \\
\hline South Africa (Pretoria) & 1 & $<0.1 \%$ & 1938 \\
\hline $\begin{array}{l}\text { St. Christopher Nevis and } \\
\text { Anguilla }\end{array}$ & 1 & $<0.1 \%$ & 1963 \\
\hline St. Lucia & 1 & $<0.1 \%$ & 1949 \\
\hline St. Vincent & 1 & $<0.1 \%$ & 1963 \\
\hline Stockholm & 1 & $<0.1 \%$ & 1977 \\
\hline Sudan & 1 & $<0.1 \%$ & 1921 \\
\hline Trondhjem (Norway) & 1 & $<0.1 \%$ & 1924 \\
\hline Turin (Italy) & 1 & $<0.1 \%$ & 2008 \\
\hline
\end{tabular}




\begin{tabular}{lccl}
\hline Issuer & $\mathbf{N}$ & $\mathbf{\%}$ Total & Dates of Issue \\
\hline Turkey/Ottoman & 1 & $<0.1 \%$ & 1928 \\
Valle del Cauca (Colombia) & 1 & $<0.1 \%$ & 1949 \\
Vienna (Austria) & 1 & $<0.1 \%$ & 1927 \\
Vietnam & 1 & $<0.1 \%$ & 2005 \\
Warsaw & 1 & $<0.1 \%$ & 1928 \\
Westphalia & 1 & $<0.1 \%$ & 1926 \\
Yokohama & 1 & $<0.1 \%$ & 1909 \\
\hline
\end{tabular}

